University of Rhode Island

DigitalCommons@URI

Open Access Master's Theses

2020

\title{
UNDERLYING VALUES IN CORAL RESTORATION: RESPONSES TO THE CORAL CRISIS
}

Cassandra Wilson

University of Rhode Island, casswils23@gmail.com

Follow this and additional works at: https://digitalcommons.uri.edu/theses

\section{Recommended Citation}

Wilson, Cassandra, "UNDERLYING VALUES IN CORAL RESTORATION: RESPONSES TO THE CORAL CRISIS" (2020). Open Access Master's Theses. Paper 1861.

https://digitalcommons.uri.edu/theses/1861

This Thesis is brought to you for free and open access by DigitalCommons@URI. It has been accepted for inclusion in Open Access Master's Theses by an authorized administrator of DigitalCommons@URI. For more information, please contact digitalcommons-group@uri.edu. 
UNDERLYING VALUES IN CORAL RESTORATION:

RESPONSES TO THE CORAL CRISIS

BY

CASSANDRA WILSON

A THESIS SUBMITTED IN PARTIAL FULFILLMENT OF THE

REQUIREMENTS FOR THE DEGREE OF

MASTER OF ARTS

IN

MARINE AFFAIRS

UNIVERSITY OF RHODE ISLAND

2020 


\section{MASTER OF ARTS}

OF

\section{CASSANDRA WILSON}

\section{APPROVED:}

Thesis Committee:

Major Professor

Amelia Moore

Elizabeth Mendenhall

Graham Forrester

Nasser H. Zawia DEAN OF THE GRADUATE SCHOOL

UNIVERSITY OF RHODE ISLAND

2020 


\begin{abstract}
Controversy has long existed among global coral experts over how to solve the coral crisis. This problem extends to the U.S. and its coral reef areas, but research on how this controversy influences restoration efforts in Florida is lacking. This study focused on Florida as an important and accessible case study to gain a closer look at the motivations behind coral conservation efforts taking place in real time. Due to a history of national and local coral legislation and consistent threats to Florida's coral reef tract, coral restoration has emerged as a legitimate form of coral-care that some reef proponents have chosen to resist the spread of reef decline in Florida. The restoration field formed in the late 1990s and continues to rapidly expand. This case study aims to fill gaps in the social literature on coral restoration, specifically from the standpoint of the study of expertise. Using a social-psychology framework for understanding values, I conducted twenty interviews with experts to explore the ways in which personal values and backgrounds of experts in the Florida coral restoration field have influenced coral-care in Florida. Throughout our interviews, coral restoration experts revealed personal values that motivated them to join the field and shared challenges to coral conservation in the Anthropocene. Values were one factor that impacted decision-making within the field. One value that some experts revealed, pristine wilderness, reflected early western and colonial conservation ideologies. As the field continues to expand, it is important for coral conservationists to reflect on their values and how it impacts the coral-care they provide. More so, to move past the challenges of the Anthropocene, conservationists in all fields must redefine their role to help the world transition into an epoch that removes
\end{abstract}


the perceived divide between humans and nature, allowing us to work collaboratively and provide multispecies care not based solely on capital or investment. 


\section{ACKNOWLEDGEMENTS}

I would first like to thank my major professor Dr. Amelia Moore for her support the past two years and for introducing me to decolonial research methods. Her focus on of equity and inclusion in scientific research allowed me to expand my views of the world and redefine my goals in the field. I would like to extend a special thank you to the twenty coral restoration experts who took time out of their very busy schedules to participate in my research. They provided me with a glimpse into their lives, sharing personal stories, lessons in coral restoration, and private challenges they face in the field. For this opportunity, I am grateful. I additionally want to thank my committee members, Dr. Elizabeth Mendenhall and Dr. Graham Forrester, for their much-needed feedback and expert opinions. In closing, I want to express my gratitude to the University of Rhode Island and the Marine Affairs Department for providing me with valuable resources and experiences that I will remember and drawn on in my next adventure. 
TABLE OF CONTENTS

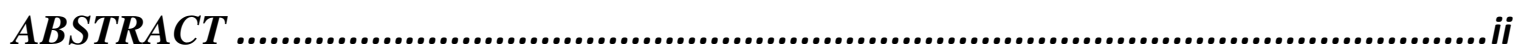

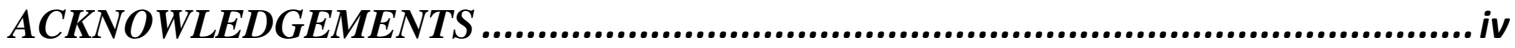

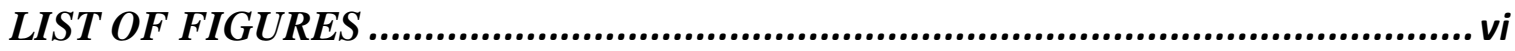

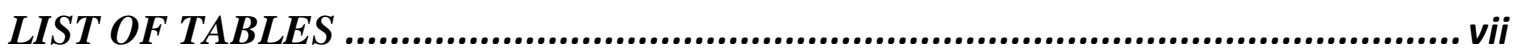

LIST OF ABBREVIATIONS........................................................................... viii

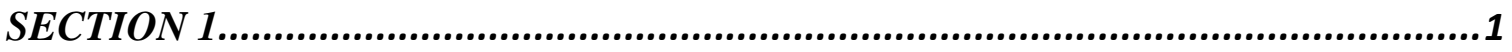

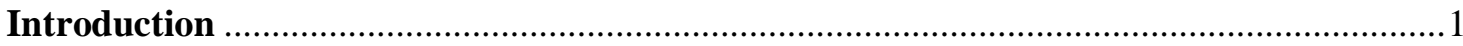

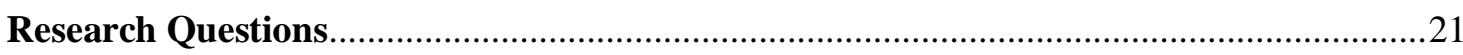

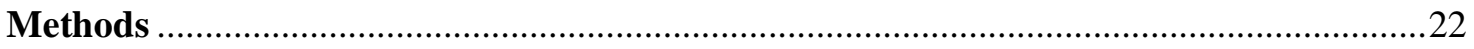

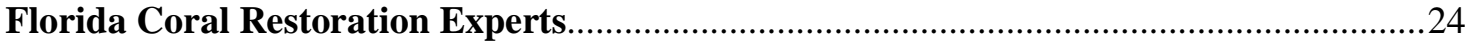

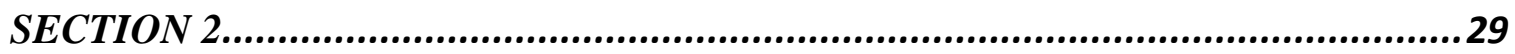

How a Changing World has impacted Florida's Coral Reef Management .........................29

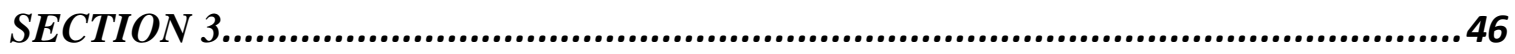

The Values of Florida's Coral Restoration Experts ………………………………….......46

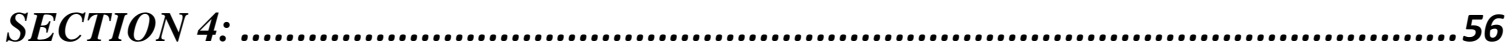

Care-Ful Conservation: How Values Influence Coral-Care in Florida .............................56

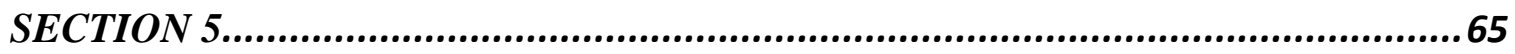

Conclusion: Envisioning Coral Reef Futures.....................................................................65

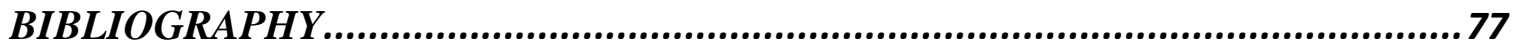




\section{LIST OF FIGURES}

Figure 1 Map depicting the location of Florida's coral reef tract (red) and corresponding management areas.............................

Figure 2 Map depicting Florida's southeast coral reef tract area (red) not included within the boundaries of the Florida Keys National Marine Sanctuary

Figure 3 Word cloud showing Florida's coral restoration experts' perceived threats to corals. The larger the text, the more often a threat was mentioned.

Figure 4a-b Micro-fragmentation of massive corals at Mote Marine Lab in Florida....

Figure 5a-b The Coral Restoration Foundation's floating coral trees used in their in-situ nurseries to grow corals to an optimal size before outplanting

Figure 6a-b The outplanting process as done by two separate organizations. Fixing coral to a substrate using an underwater epoxy (A); arranging micro-fragments to a substrate using

Figure 7 Pie graphs showing the demographics of Florida's coral restoration experts included in study $(\mathrm{n}=20)$. Variables included are "Sex" (blue), "Level of Education" (purple).

Figure 8 Map showing the jurisdiction of the South Atlantic Fishery Management Council (orange) and the Gulf of Mexico Fishery Management Council (red). Jurisdiction is split. 


\section{LIST OF TABLES}

Table 1 Values of experts $(n=20)$ found in each value orientation: social altruism, egoistic altruism, and biospheric..................... 48 


\section{LIST OF ABBREVIATIONS}

$\begin{array}{ll}\text { Abbreviation: } & \text { Description: } \\ \text { FKNMS } & \text { Florida Keys National Marine Sanctuary } \\ \text { SST } & \text { Sea Surface Temperature } \\ \text { DHW } & \text { Degree Heating Week } \\ \text { SCTLD } & \text { Stony Coral Tissue Loss Disease } \\ \text { DEP } & \text { Department of Environmental Protection } \\ \text { SAFMC } & \text { South Atlantic Fishery Management Council } \\ \text { GMFMC } & \text { Gulf of Mexico Fishery Management Council } \\ \text { CRTF } & \text { Coral Reef Task Force } \\ \text { NPS } & \text { National Park Service } \\ \text { USGS } & \text { United Stated Geological Survey } \\ \text { TNC } & \text { The Nature Conservancy } \\ \text { CRC } & \text { Coral Restoration Consortium } \\ \text { CRCP } & \text { Coral Reef Conservation Program }\end{array}$




\section{SECTION 1}

\section{Introduction}

\section{Changing Coral Relationships}

Coral reef ecosystems, occupying less than $1 \%$ of the world's oceans, are widely recognized as biodiversity hotspots (Knowleton et al. 2010). Corals play an important role in these ecosystems, acting as ecosystem engineers (Jones et al. 1994). In this role, corals influence or control the availability of habitat for other species. Corals are also considered foundation species as they help alleviate the stress of survival for other organisms, such as fish, by creating a refuge for them to escape predators (Dayton 1972; Angelini et al. 2011). Coral reefs provide many important ecosystem goods and services, and because of this, they are socially, biologically, and economically important marine ecosystems for global and local communities. Among other benefits, coral reefs provide habitat for marine organisms, a source of revenue from tourism, food for people, storm protection, and medicinal resources (Barbier et al. 2011; Moberg and Folk 1999).

\section{The Global Coral Crisis}

Despite their global significance, coral reefs are facing many anthropogenic challenges to survival. Globally, consumptive and non-consumptive activities have historically resulted in mass mortality of corals, and the continuance of these activities, especially those contributing to climate change, threatens the long-term survival of reefs. Members of the global coral community characterize rising greenhouse gas emissions, eutrophication, overfishing, and unsustainable tourism as common activities that lead to major coral reef degradation ("Threats to Coral Reefs" 2018; Selkoe et al. 2009; Hoegh- 
Guldberg 1999). However, many argue that climate change is most catastrophic of them all (Hoegh Guldberg 1999; Eakin et al. 2010). Increasing atmospheric concentrations of carbon dioxide in the atmosphere leads to ocean acidification, compromising the calcium carbonate skeleton accretion necessary for coral growth (Kleypas et al. 1999; HoeghGuldberg et al. 2007). Additionally, high concentrations of $\mathrm{CO}_{2}$ and other greenhouse gases have resulted in warming sea surface temperatures (SSTs), which have provoked global bleaching events and mass mortality of the world's coral in as little as a single year ("Threats to Coral Reefs" 2018).

Coral bleaching occurs when warming SSTs cause corals to expel their symbiont zooxanthellae, resulting in ghostly, white-colored corals (Eakin et al. 2010; Lesser 2011; "Coral Bleaching" 2018). Without their zooxanthellae, corals are increasingly vulnerable to local threats. While there are multiple causes of coral bleaching, corals most often bleach when SST warms corals past their thermal tolerance level. This threshold, also referred to as a thermal limit, is typically $1^{\circ} \mathrm{C}$ above the average maximum SST for an area (Eakin et al. 2010; Hoegh-Guldberg 2011; Strong et al. 1996; "Satellites and Bleaching" 2019). If warming waters persist over time in an area, the impacts worsen. Mass coral bleaching typically occurs when heat anomalies reach $4^{\circ} \mathrm{C}$ Degree Heating Weeks (DHW). This means that over a 3-month timescale in a given place, SSTs were consistently above the local average. Mass coral mortality is common when SSTs reach $8^{\circ} \mathrm{C}$-weeks (Eakin et al. 2010; Hoegh-Guldberg 2011). DHWs are a measure of both the size and length of heat anomalies (Strong et al. 1996). Repeated and long-lasting heat anomalies can leave corals less resilient to future bleaching events and local threats. 
While the threat of rising SSTs has received increased media attention in response to the latest coral bleaching event, scientists have known about the threat since the first global bleaching event, which occurred from 1997-1999 (Hoegh-Guldberg 1999; Braverman 2018). Prompted by intense El Niño and La Niña events, corals around the world began to die as they were heated and then cooled past their thresholds. Similar mass mortality events have occurred in both 2010 and most recently in 2014-2017. The most recent global heat anomaly resulted in coral bleaching of $>91 \%$ of Australia's Great Barrier Reef (Hughes et al. 2017). It is predicted that these events have and will continue to occur more frequently as the Earth and SSTs continue to warm (Hoegh-Guldberg 1999).

\section{Local Responses}

Local threats compound global threats, and individually they also have the potential to result in mass mortality of coral in a given area. For example, Florida's coral reef tract, extending from Dry Tortuga's National Park to Martin County (fig. 1-2) has consistently faced common and unique challenges to survival over the past 40 years, with coral cover continuously declining since 1996 (Jackson et al. 2014; Wilkinson and Souter 2008). Past and ongoing disease outbreaks have led to significant reductions in percent coral cover and diversity. In the late 1970s and 1980s, a water-borne pathogen, labeled the white band disease, targeted Florida's major reef building coral species, Acropora cervicornis (staghorn coral) and Acropora palmata (elkhorn coral) ("Coral Diseases" 2018). 


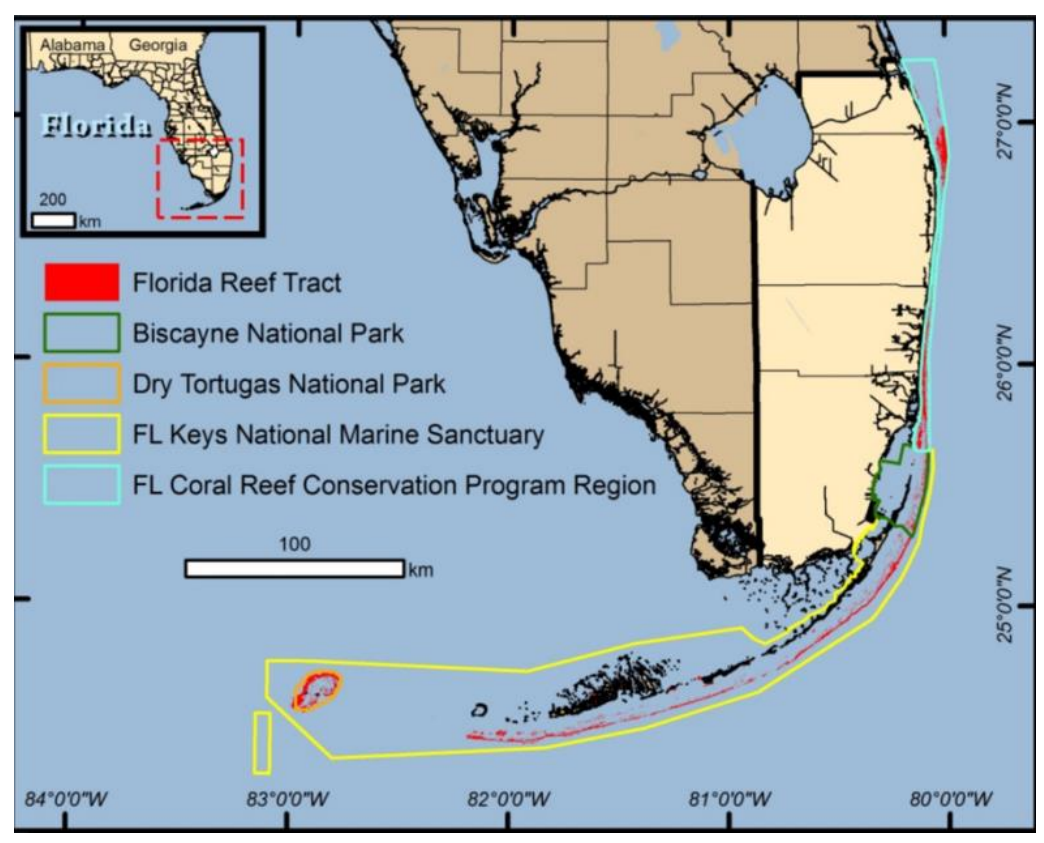

Figure 1: Map depicting the location of Florida's coral reef tract (red) and corresponding management areas (Gregg 2013). 


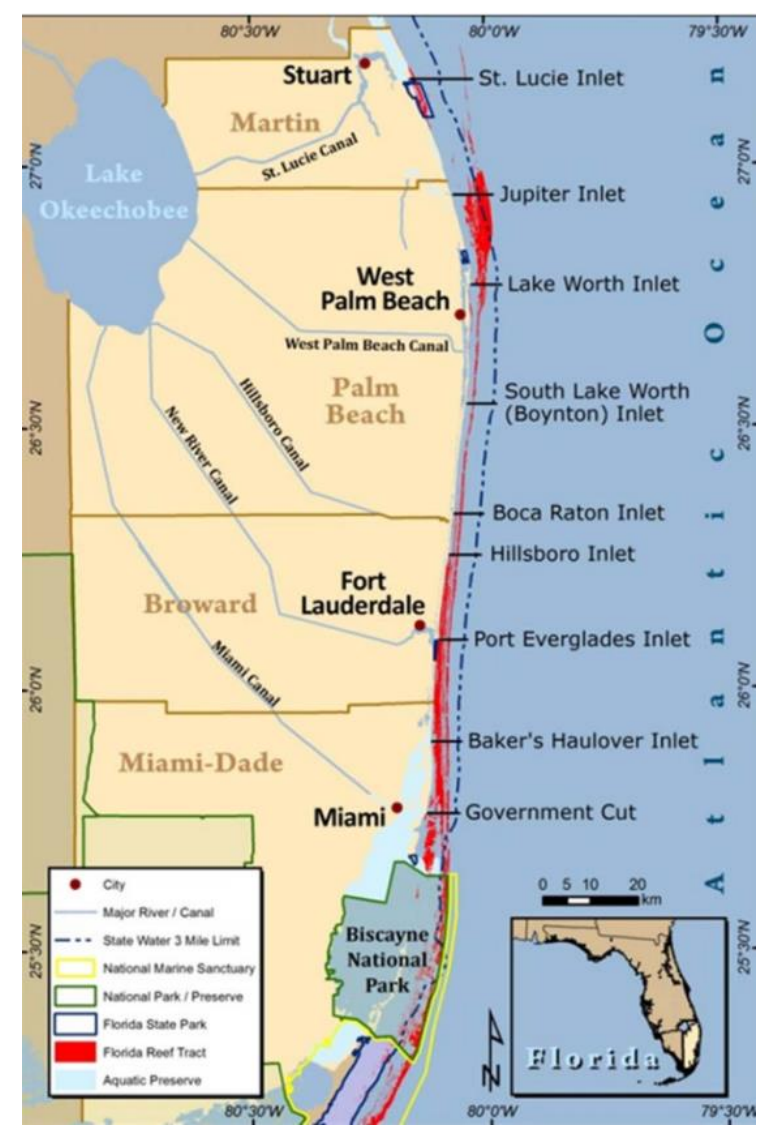

Figure 2: Map depicting Florida's southeast coral reef tract area (red) outside of the boundaries of the Florida Keys National Marine Sanctuary (Gregg 2013).

The white band disease killed $95 \%$ of staghorn and elkhorn corals in the Florida Keys, and the effects of this loss are still noticeable today (Wilkinson and Souter 2008; personal communication 20191). Around the same time, populations of an important algae-consuming sea urchin, Diadema antillarum, began dying off due to disease spreading through Panama's Caribbean waters. This disease quickly spread to Florida's waters and impacted Florida's Diadema populations, resulting in a shift from coral dominated reefs to algal dominated reefs (Lessios 2016; Wilkinson and Souter 2008). Another coral disease, the black band disease, annually threatens over 40 coral species in

1 Interviews cited as "personal communication" when interviewees did not consent to waive their confidentiality 
Florida and originates from environmental factors, such as pollution, sedimentation, and warming waters (USGS n.d.; "Coral Diseases" 2018; personal communication 2019). While Florida's coral reef tract has a complex history of disease outbreaks, no disease epidemic is as severe as the ongoing Stony Coral Tissue Loss Disease (SCTLD), which began in 2014 (personal communication 2019; "Florida Coral Disease" 2019). A lead coral scientist working in Florida stated that “...this disease has for some species a $100 \%$ mortality rate. With that coral or that species that gets infected, there's no chance for it to survive. Corals that take centuries to grow, like say the size of a chair, can be completely killed in just weeks." (personal communication 2019). The cause of the outbreak is unknown and may not be determined for years, however, many members of Florida's coral community have speculated that poor water quality led to the outbreak ("Florida Coral Disease" 2019; personal communication 2019).

In addition to disease, local increases in SST have resulted in several localized bleaching events. The Florida Keys experienced massive coral bleaching in 1998 due to an increase in SSTs (Wilkinson and Souter 2008). Later in 2005, Florida and the Caribbean experienced a record high heat anomaly greater than $16^{\circ} \mathrm{C}$-weeks, exceeding the DHW typically associated with mass bleaching and mortality events (Eakin et al. 2010; Hoegh-Guldberg 2011). The passing of Hurricane Katrina fortuitously saved Florida's corals from mass mortality, but the threat of coral bleaching still exists as climate conditions worsen.

During an interview with Dr. Josh Patterson2, an expert coral aquaculturist in Florida, he explained the present state of Florida's reefs, bluntly stating, "Florida is pretty 
bad. Florida is maybe what the great barrier reef would look like in 20 years" (Patterson, personal communication 2019). As Florida's corals continue to face both extreme global and local threats to survival, Florida's coral community, consisting of both professional and amateur coral experts, faces many challenges to overcoming these threats. Dr. David Gilliam, a well-known coral scientist working at NOVA Southeastern University, described what it is like working in Florida's current environment, stating, "We're at the intersection of global stress and local stress right here and it creates an interesting environment to work in and a lot of questions" (Gilliam, personal communication 2019). While global SSTs continue to rise, Florida corals are additionally experiencing poor water quality, unsustainable tourism, overfishing, intense storms, and pollution (personal communication 2019; "Florida Coral Disease" 2019; Wilkinson and Souter 2008). As one Florida coral restoration practitioner puts it, Florida's corals are facing a "death by a thousand cuts" (fig. 3) (personal communication 2019). 


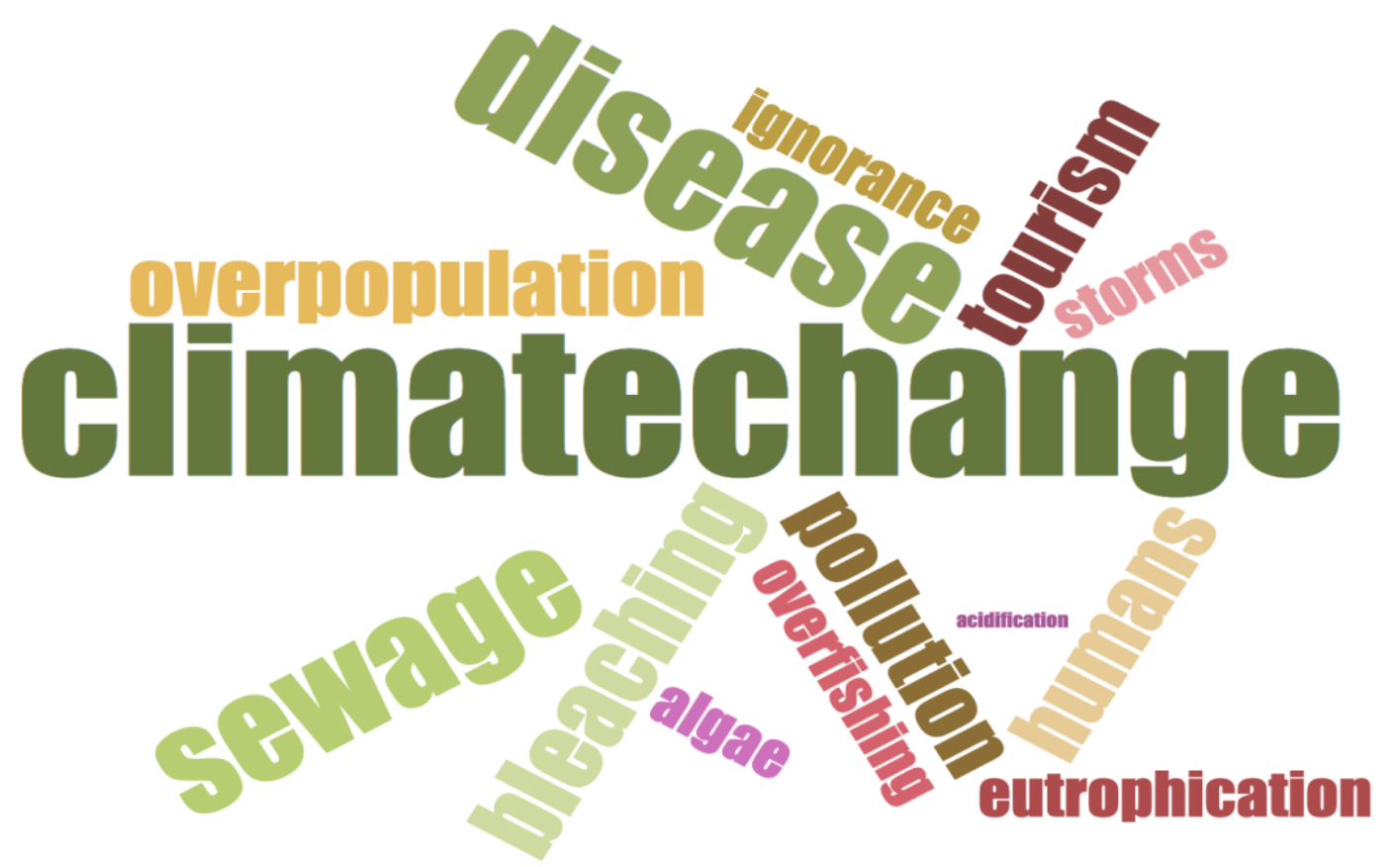

Figure 3: Word cloud showing Florida's coral restoration experts' perceived threats to corals. The larger the text, the more often a threat was mentioned.

Some members of Florida's coral community additionally argue that the American public is ignorant to the challenges coral reefs face (fig. 3). Tom Moore, NOAA's Coral Restoration Team Lead stated that "the biggest threat is people, and the people don't even realize that they're the threat. Obviously, this is the case with lots of ecosystems in lots of different places, but it is even worse in an ecosystem where people can't see it and all they can do is hear about it" (Moore, personal communication 2019). This lack of education or awareness is viewed by many as a major barrier to reducing the threats to Florida's coral reefs (personal communication 2019). Overall, many members of Florida's coral community believe that determining the site of local threats and raising public awareness of these issues, such as about the spread of SCTLD, is necessary when conducting conservation projects on a local scale, arguing that local threats reduce coral reefs' resilience to global threats. Therefore, it is hoped that by reducing local threats, the 
corals' overall resilience to global threats will increase (personal communication 2019; Braverman 2018).

\section{The Global Coral Conversation}

In the wake of continued threats to corals around the world, a global community of coral conservationists find themselves tasked with determining solutions to the coral crisis. Within this community are experts, or leading coral scientists, managers, educators, and activists that are prominent voices for the community. However, finding a solution to the coral crisis has sparked controversy among the global coral community. Following the third global-bleaching event in 2017, Irus Braverman's book Coral Whisperers offers a unique glimpse into the minds of coral scientists who are in the midst of the crisis. She highlights the controversy that exists between the scientists and identifies the different perceptions of future outcomes, including A) the doom and gloom perspective, B) the hopeful perspective, and C) somewhere in between. From these differing perspectives come different methods for conservation, where hopeful scientists tend to favor coral restoration efforts, or the physical outplanting of corals onto reefs, more so than those of the doom and gloom perspective, who favor larger, global actions, such as climate change mitigation (Braverman 2018).

What has ensued is a debate between coral reef restoration and climate change mitigation. Coral restoration proponents see it as a way to increase a local reefs resiliency to global stressors, a method of "buying time" until climate change and other local threats are alleviated, and part of the solution, meant to be conducted in combination with other methods of coral protection. On the other hand, restoration opponents view restoration as 
taking resources away from climate change mitigation, a "waste of time" and a Band-Aid solution that promotes avoidance of the real problems as it allows for corals to be placed back in compromised environments (Braverman 2018; personal communication 2019). This heated dichotomy between climate change mitigation and coral restoration set the stage for my research, where this study focuses on actions and actors in the American state of Florida as an important and accessible case study to gain a closer look at the effects of the controversy on actual coral conservation efforts taking place in real time.

\section{Coral Restoration Methods}

Like the different methods for conservation, there are many methods for coral restoration, as the field is still in its early developmental stages. Coral restoration in Florida is done both for research purposes and population enhancement in Florida waters (personal communication 2019). All projects require special permits, and within sanctuary boundaries, organizations must obtain a permit from the FWC and the sanctuary (personal communication 2019). Restoration projects in Florida thus far have focused on restoring genotypically diverse Acropora populations as well as populations

of other important corals, such as boulder corals. Within Florida's coral restoration field, multiple organizations conduct and collaboratively manage restoration efforts, including but not limited to NOAA, TNC, FWC, the FKNMS Sanctuary Staff, the University of Florida, the University of Miami, Mote Marine Laboratory, the Coral Restoration Foundation, the Florida Aquarium, and Coral Vita. There is no singular method for coral restoration, and many organizations have created or adopted a method that works best for 
them. However, because it is a newer field, restoration methods are regularly evolving to become more effective, efficient, and/or easy to do.

Before coral animals can be outplanted onto reefs, they must first be produced, either through sexual or asexual reproduction. Sexual reproduction is the favorable method of coral production because it allows for genetic variation, yet scientists have yet to master lab-induced coral sexual reproduction. Many coral species only spawn, or sexually reproduce, one time per year after sunset (NOAA 2011; Patterson, personal communication 2019). When corals spawn, they release both sperm and eggs into the water column for fertilization. Collecting these gametes proves challenging, both because the scheduling has to be perfect and since corals spawn at night, it can be a taxing field experience for scientists (Patterson, personal communication 2019). As a result, it is difficult for restoration practitioners to utilize sexual reproduction methods to grow coral populations for coral restoration. However, recently in 2019 the Florida Aquarium's Project Coral made a scientific breakthrough where researchers were able to induce coral spawning in one coral species through mimicking the ocean environment and temperature and light patterns. While this process has not yet been mastered, the Aquarium's efforts are historic because this was the first-ever successful scientist-induced coral sexual reproduction at the Aquarium lab (Patterson, personal communication 2019; Johnson 2019).

While scientists continue to test methods for sexual reproduction of corals, asexual reproduction is much easier to come by. Commonly referred to as "coral gardening," many coral restoration organizations in Florida use harvested or rescued wild coral colony samples that are already fragmented or easy to fragment, and then propagate 
these corals in in situ or ex situ nurseries before they are outplanted onto pre-designated Florida reef locations (Braverman 2018; personal communication 2019; Page et al. 2018). Rescue coral fragments are obtained after storm events, anchor damage, or other disturbances (personal communication 2019). NOAA's first coral restoration efforts began will coral rescue missions after ship grounding in the Keys. NOAA continues to do some rescue efforts and TNC additionally has worked to rescue corals that are susceptible to the Stony Coral Tissue Loss Disease but have not contracted it yet (personal communication 2019)

There is a collaborative effort in Florida to maintain genetic diversity of reefs, and because of this, many organizations store genotypically diverse corals in their nurseries and selectively breed corals (personal communication 2019). CRF since its beginning has collected roughly 300 genotypes from 6 different coral species for in situ coral cultivation (Levy et al. 2018). Mote additionally cultivates 20+ rescued species of corals in its in situ and land-based nurseries. Nurseries offer a way for organizations to continue restoration without having to continuously retrieve samples from wild reef populations. More so, storing genetic information ensures the survival of genetic variation in the event that coral species go extinct.

The coral gardening process was initially easiest for fast-growing coral species, but these corals are typically more susceptible to thermal intolerance (Loya et al. 2001; Page et al. 2018). Massive, slow growing corals that have a higher thermal tolerance and are important reef-builders are more difficult to rear, but since the revolutionary invention of micro-fragmenting, restoration practitioners can now grow these corals in nurseries at a larger scale. David Vaughan, a scientist at Mote, accidentally discovered 
this method in 2013 (Page et al. 2018). Micro-fragmenting entails cutting massive corals, such as brain and boulder corals into as small a size as possible, typically around $1 \mathrm{~cm} 2$ portions (fig. 4a-b). These portions are then attached to a puck and grown in land-based nurseries (Boyce n.d.). This process speeds up growth. An expert coral scientist, manager, and practitioner explained that micro-fragmenting elkhorn in Florida "accelerates a growth rate up to 50 times faster and triggers growth response. This species typically grows a few millimeters a year out on the reef. With this technique, it basically grows up to 50 times faster and should get centimeters of growth each year" (personal communication 2019). Because of this, micro-fragmentation is widely used in Florida as a method for asexual reproduction.

A

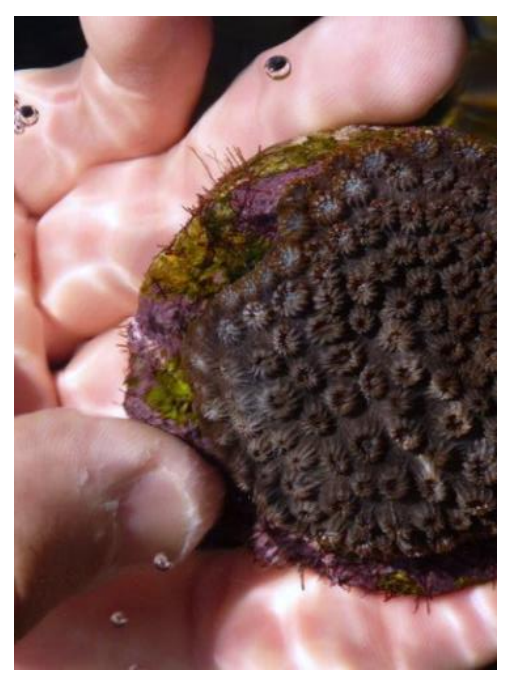

B

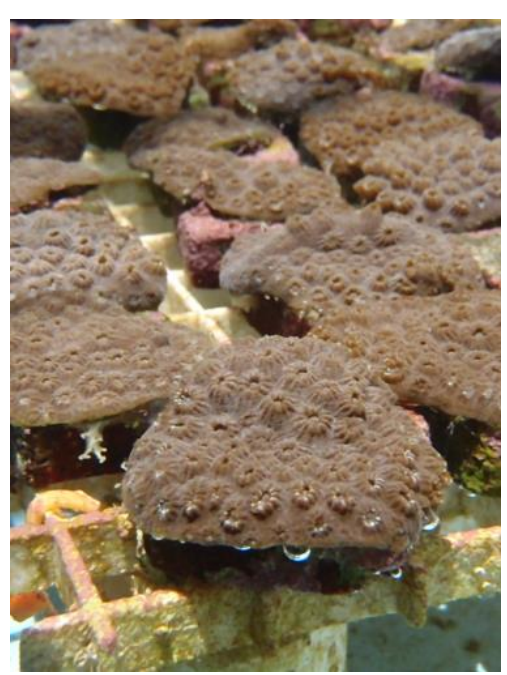

Figure 4a-b: Micro-fragmentation of massive corals at Mote Marine Lab in Florida.

While micro-fragmentation is conducted in land-based nurseries, many organizations utilize floating or fixed structures to grow corals in in situ nurseries (fig. 5a-b). Corals are attached to structures that are suspended in the water column or are fixed to the ocean floor. Utilizing floating structures is the most common method for in 
situ nursery propagation (The Nature Conservancy 2020; personal communication 2019). Because the field is new and evolving, many organizations, such as NOAA, the University of Miami, and NOVA Southeastern University conduct or fund research projects that employ various methods of nursery propagation to determine which are most effective.

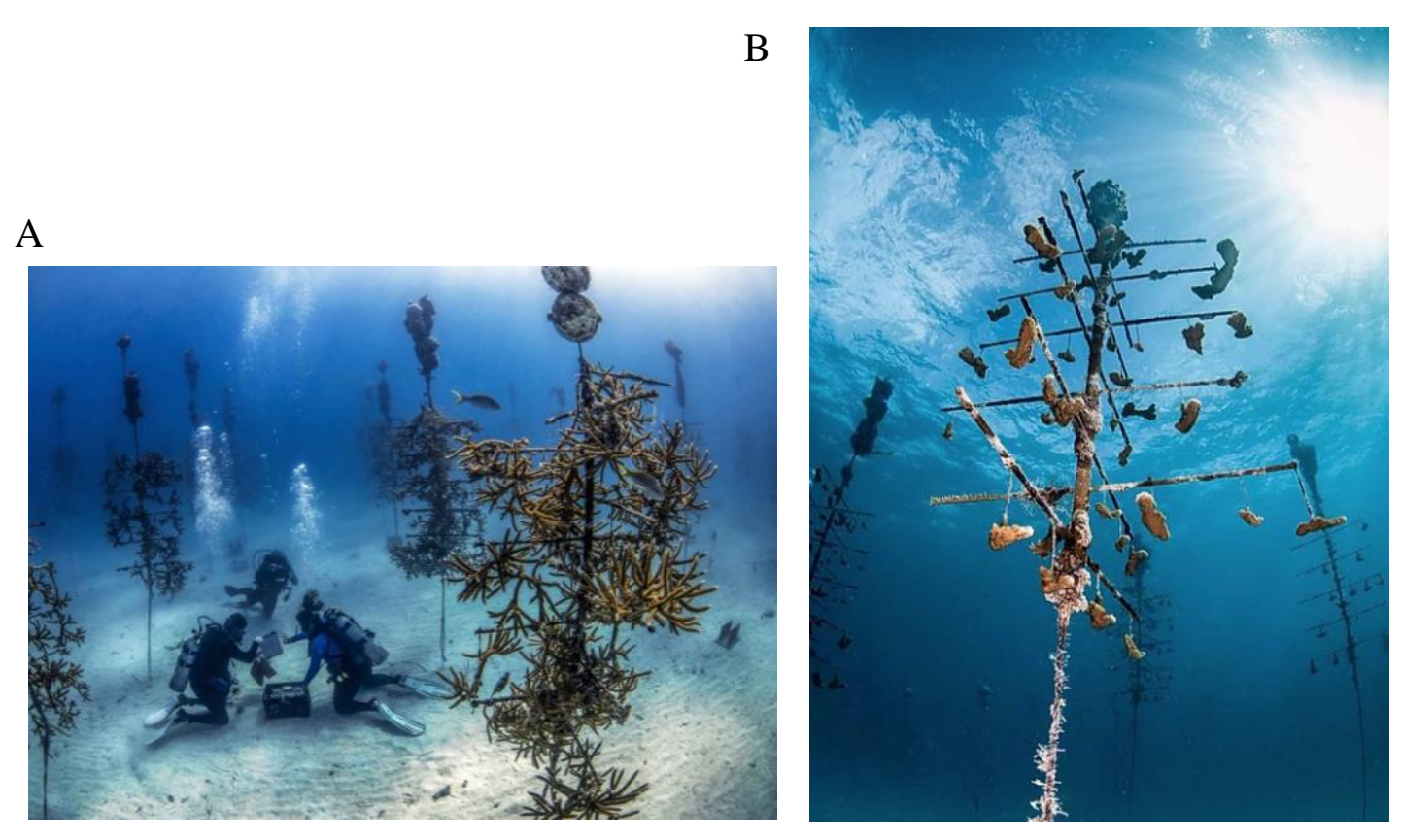

Figure 5a-b: The Coral Restoration Foundation's floating coral trees used in their in-situ nurseries to grow corals to an optimal size before outplanting.

Corals are outplanted onto reefs in Florida in a myriad of ways (fig. 6a-b). Once corals grow to an optimal size in in situ or land-based nurseries, they are either fragmented again or transported to a reef location and individually and manually fastened to the substrate. Massive corals take around 12 months to reach an optimal outplant size (personal communication 2019). Outplant locations are typically on raised reefs or dead coral heads (personal communication 2019). Several organizations utilize an underwater cement or epoxy to attach corals to the substrate. Another way to fasten corals without 
using an epoxy is to use an underwater drill to make a hole in the substrate. Corals are attached to plugs that fit into these drill holes (personal communication 2019).

Organizations in Florida use identifiable markers or tags during each outplant project to label corals in order to monitor their growth. Within the FKNMS, monitoring is required after one month to ensure that corals have survived and then after one year to ensure corals have adapted to the environment per FWC and sanctuary permit regulations. Some organizations in the Keys monitor more often, but because monitoring is time intensive and not required beyond one year, most restoration sites are not regularly revisited (personal communication 2019).

A

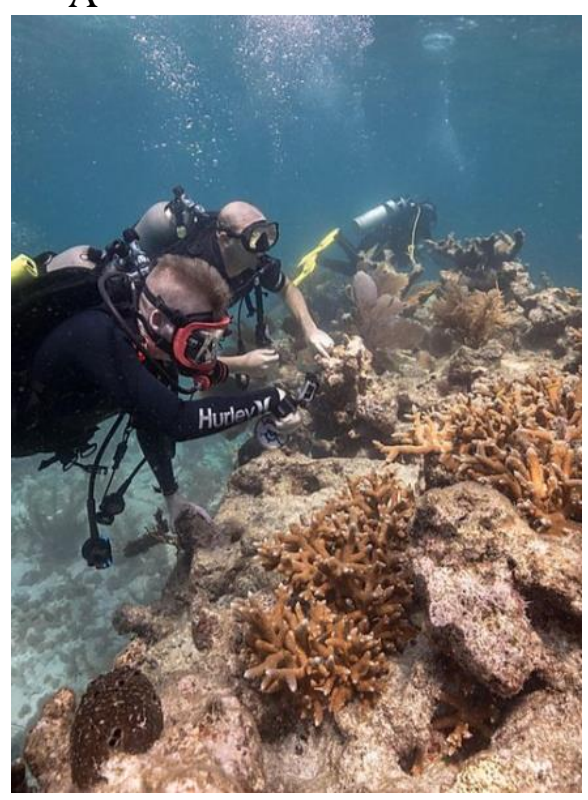

$\mathrm{B}$

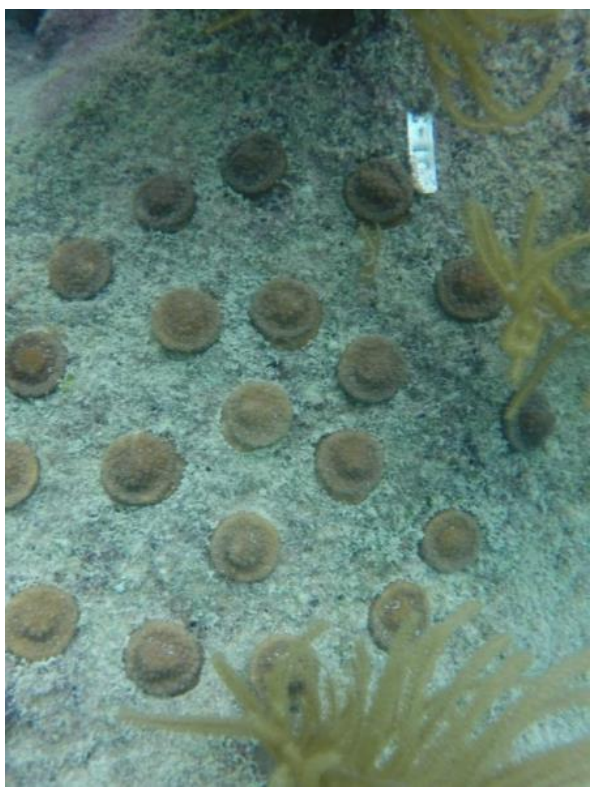

Figure 6a-b: The outplanting process as done by two separate organizations. Fixing coral to a substrate using an underwater epoxy (A); arranging micro-fragments to a substrate using drill holes and plugs $(B)$.

Coral restoration is the most active and radical method of coral conservation in Florida and the field employs both monitoring and research to improve its process. As 
Florida's coral restoration field rapidly grows, organizations are developing new methods and goals of restoration that will have an impact on coral reef futures.

\section{Values in the Anthropocene}

I chose to place my research in the context of the Anthropocene. The Anthropocene is generally defined as a point in recent history where human activities began influencing or transforming all planetary systems (Haraway 2016; Moore 2019; Lorimer 2015). Dr. Amelia Moore, an anthropologist, further describes the Anthropocene as "evidence of a philosophical shift in the way many people come to know their world, themselves, and their relationship to other living things" (Moore 2019). The Anthropocene is more than a shift in time - it is a new way of thinking — and with this new thought, comes new adaptations and responses to environmental crises. While many scholars debate the Anthropocene philosophy, I chose this context because this new way of thinking has resulted in efforts like ecological restoration. As anthropogenic threats to ecosystems have increased over the past several decades, there have been efforts to expand and scale-up ecological restoration efforts (Perring et al. 2018). These efforts exemplify a common response to the Anthropocene, as restoration practitioners are attempting to use science, technology and innovation to reverse or lessen the damage of anthropogenic threats (Lorimer 2015).

Some of these efforts focus on restoring pristine wilderness, a contested idea that dates back to the transcendentalist movement and perpetuates an understanding of humans and nature as separate. The topic of wilderness is classically defined in William Cronon's critique of wilderness as locations untouched by man and free of man's 
destructive capacity; therefore, to return to wilderness one must remove humans from the environment (Cronon 1996). These ideas are rooted in colonialism and elite whiteness, and because of this, they advocate for the inequitable removal of people from environments. Wilderness ignores the histories of indigenous people that occupy "wild" areas and promotes the removal of these groups and other minorities for the benefit of a rich, patriarchal society (Cronon 1996).

In addition to science, the restoration ecology literature acknowledges the role values play in restoration project planning. In social psychology, values are generally defined as the underlying principles that help us make decisions, especially when there are tradeoffs (Hitlin and Piliavin 2004; Dietz et al. 2005). The process of determining restoration goals and objectives is increasingly seen in restoration ecology as value laden. Determining which ecosystem state is healthy requires one to both understand ecological science and make ideological value-judgements as to the state of the ecosystem that is most desirable for either society, oneself, or the environment (Davis and Slobodkin 2004; Hobbs 2002; Choi 2004; Choi 2007). However, current conversations around ideal baselines are deeply rooted in ecological justifications. Thus, the role of values is sometimes ignored in restoration fields.

The Anthropocene time period and way of thinking presents many challenges for ecological restoration, and more broadly, conservation management. Scientists and managers must decide which species to save and how to save them. Yet because values are not readily called upon in decision-making in all conservation fields, these decisions are not always transparent. Worsening climate conditions in these unprecedented times forces scientists and managers to make these decisions with a high level of uncertainty. 
Forms of care in the Anthropocene (or methods of species protection) like ecological restoration, while intended to save, are not always so benign, and efforts to change the composition of the natural world can result in unintended and lasting ecological, social, and economic consequences. Additionally, as shown through the global coral restoration controversy, some scientists and managers perceive tradeoffs between different forms of care. Because of this, it is important for conservationists to reflect on their values and the impacts these values can have on the type of care, or protection, that they are advocating for.

\section{Florida Case Study}

Restoration projects and the controversies surrounding them are not novel in Florida. Everglades restoration projects have been highly controversial and because of this are similar to the coral restoration controversy. I chose this research as a case study to show the challenges of people who have put themselves on the front lines of American coral conservation, and the complexities and controversies that surround conservation work in the Anthropocene. I specifically chose Florida because it has one of largest reef tracks (Florida DEP 2019) and has both an extensive legal history of coral protection and policy and history of coral degradation. Additionally, over the past decade, the Florida Keys has quickly become a leader in global coral restoration efforts.

Irus Braverman's book Coral Whisperers opened the door for the social study of coral around the world. My research builds on the existing coral conversation by taking an in-depth look at coral restoration from the American perspective. I focus on values to determine what motivates decision-making in the field as a way to better understand the 
American complexities and controversies of restoration. While the restoration ecology literature readily acknowledges the role values play in restoration project planning (Davis and Slobodkin 2004; Hobbs 2002; Choi 2004; Choi 2007) the expansion of Florida's restoration field is rapid and ongoing and the literature has yet to catch up with events on the ground.

Therefore, this study aims to fill some of the gaps in the literature on coral conservation and restoration, specifically from the standpoint of the social study of expertise. It is important for coastal managers, policy makers, and the American public to understand who the leaders behind the Florida restoration movement are, how they make decisions, and why they advocate for certain solutions over others in order to achieve a greater understanding of the following: 1) the stakes and challenges of people who have put themselves on the front lines of American coral conservation 2) the controversies that surround coral restoration as a microcosm for understanding the scientific challenges of the Anthropocene, 3) how key conservationists function under conditions of uncertainty, and 4) the social, cultural, political, and scientific complexities of coral restoration in the American context. As Florida's restoration field continues to expand, there is a growing need for increased transparency. This study has the potential to increase the understanding of the politics of restoration through identification of experts' values and goals for restoration projects. My research is additionally an opportunity to open channels for communication between coral conservation experts on all sides of the global debate to facilitate cooperative efforts to conserve the world's remaining coral. 


\section{Experts}

Chi, Glaser, and Farr (1988) define experts as individuals who excel in their chosen field due to their extensive knowledge of the field. Additionally, they acknowledge that while experts can take longer to perform initial steps towards solving a problem, they consistently solve problems more quickly than beginners. More so, experts have the ability to represent and understand problems on a deeper level than less experienced individuals. Lastly, Chi, Glaser, and Farr (1988) found that experts are more likely to be aware and critical of self-error than others. Similar to these findings, Ericsson (1998) argues that expertise forms when an individual trains and practices an activity extensively. Typically, the level of expertise increases with time, where individuals who have spent more time in a field gain additional skill sets only acquired through active training and practice.

Expertise is utilized for solving practical problems in different contexts (Carrier 2010). Therefore, people rely on experts in a field to solve problems by contributing suitable and reliable solutions. Overall, experts, and the qualifications of experts, is understudied in many fields (Boyer 2008). In the context of this study, experts are defined as experienced individuals in the Florida coral restoration field. Experts were chosen as subjects for this study because the role of experts is understudied in the growing coral restoration field in Florida. Moreover, there are studies that outline the biological successes and failures of various coral restoration strategies, but few utilize social science to determine the values held by experts in this field and how that translates into restoration practice. It is important to determine and understand why people are making certain choices, interpreting conflicts and challenges, and advocating for 
solutions based on their expertise, values, and personal history. Experts in this field are significant because they are the leaders of Florida's coral restoration efforts and contribute strongly to the global conversation on coral conservation. What happens in Florida may not stay in Florida. Likewise, strategies and arguments originating from other parts of the world, such as Australia, may strongly influence expert strategies in Florida.

\section{Research Questions}

This study aims to explore one overarching research question: In what ways have the personal values and backgrounds of experts in the Florida coral restoration field influenced the goals and methods of coral conservation in Florida? Additionally, five sub-questions are intended to further illuminate the field of coral restoration in Florida and define the scope of this study. These questions are as follows: 1) Who are the different experts in Florida and what counts as expertise in this field? 2) What are the varying values and backgrounds of these experts? 3) How do different experts perceive the goals of coral restoration and do different experts perceive goals differently? 4) How do coral restoration experts articulate their role in coral policy creation in Florida or globally? And finally, 5) How do these experts approach the question of "shifting coral baselines" and does their perception of that issue affect their attitude towards restoration efforts (as either successful or unsuccessful)?

Because coral cover in Florida has consistently declined since the mid 1900s, many experts and members of Florida's coral community have different ideas of what a reef should look like, resulting in a phenomenon called "shifting [coral] baselines" (Pauly 1995). This issue extends beyond Florida's coral community to members of the public. 
Richard Vevers, the founder of The Ocean Agency nonprofit and a key cast member in the Netflix documentary Chasing Coral, describes this issue well: "The number of times I've jumped into a very damaged environment and it looks spectacular...but it was only once I saw what it should have been, that I realized what we've lost." (Richard Vevers, personal communication 2019). To someone who does not work on a reef weekly, monthly, or even yearly, underwater experiences may still fill one with awe and wonder. Without prior knowledge or exposure to a reef, it is difficult to know its history. This history is important to reflect on, as extractive human actions, such as tourism and industry, have resulted in harm to the marine environment. Yet as we move forward beyond the Anthropocene, the role of baselines needs further evaluation.

\section{Methods}

Data collection took place from June 2019-October 2019. While my research was based in Florida, my sample size more broadly consisted of Florida coral restoration experts living in Florida and outside of Florida at the time of the study. I use an interpretivist approach, where I focused on individual experts and the reality they have created (Robson and McCarten 2016). This approach assumes that people's values, attitudes, and beliefs are a result of how they interpret the social world. Interpretivists acknowledge that there is no single reality; rather, each individual constructs their own reality in which they live (Robson and McCarten 2016). I used semi-structured interviews for data collection

To ensure successful interviews, I actively listened, clearly state questions without pressuring interviewees to respond, and remained neutral in my own actions and responses to avoid cues that might influence interviewee responses (Robson and 
McCarten 2016). I also utilized techniques, such as probing, throughout each interview. Probing is a skill that interviewers can use to encourage participants to expand on their responses, especially when it appears participants have not divulged their entire response. For example, the "silent probe" consists of remaining quiet after a participant has answered a question to allow them the opportunity to add additional information (Bernard 2011). Another example is the "tell-me-more" probe, where the interviewer asks the participant to describe a previous statement in more detail (Bernard 2011; Robson and McCarten 2016). Finally, during each interview, the sequence of questions began with broad and simple questions to allow the participant time to open up. Questions became more focused and targeted as the interview progressed.

\section{Semi-Structured Interviews}

I conducted twenty semi-structured interviews with coral restoration experts that were working or had previously worked for public, private, and nonprofit organizations and agencies in Florida. The interviews ranged from 20-60 minutes and on average lasted around 40 minutes. All interviews were conducted face-to-face at each organization unless participants were not located in Florida at the time of the study. In such cases, I conducted Skype or phone interviews. Overall, I conducted five in-person interviews, three Skype interviews, and twelve phone interviews. I first identified ten coral restoration experts based on publicly available information online-agency and organizational websites and available literature. I contacted all participants first via email. To ensure the representativeness of the sample size, I supplemented remote identification with on-site referrals using snowball sampling. The reliability of the study was 
maintained by recording all interviews, utilizing non-leading questions, and providing neutral information to participants.

The generalizability and external validity of this study are limited to Florida's coral restoration field due to the nature of the research questions and the methods employed. To ensure the ethical appropriateness of this study, all interviewees who requested it will remain confidential and no identifiable information will be included in this thesis without participants' explicit consent. All participants were primed for the intended use of the interview responses and each participant was required to read and sign a consent form before the interview began. All data, specifically the recordings, transcriptions, and all identifying participant information, are located on an encrypted flash drive for safe keeping.

\section{Florida Coral Restoration Experts}

Of the methods for coral protection in Florida, coral restoration efforts are the most publicly criticized and measures of restoration efficacy are widely contested (Braverman 2018). This begs the question. Who are the people advocating for coral restoration, and why have they chosen to work in this field in Florida? Coral restoration in Florida is a very new field. Despite this, experts in this community have diverse and varying backgrounds, experience levels, ages, and reasons for joining. Through my interviews with experts, I found that values and job opportunity predominantly influenced individuals to choose the field of coral restoration. For some people, working in coral conservation and restoration in Florida can be a steppingstone or roundabout way for some people to work in fisheries management. For example, one federal coral restoration worker shared with me that they are only participating in this work to advance their 
career because experience working with coral habitats better qualifies them to work in fisheries management (personal communication 2019). Other experts had intended to work in a different field but one day found themselves working with corals due to job availability. With the coral restoration field growing, many opportunities for work have arisen in the past 20 years. As Dr. David Gilliam from NOVA Southeastern University puts it, “...when I was finishing with my doctorate, there seemed to be more opportunities doing benthic work than fish work and so I just went where the doors were open and trained myself to become a benthic person, a coral person" (Gilliam, personal communication 2019).

However, while some experts never envisioned themselves in this field, many from a young age were eager to work in coral protection. After first learning about coral restoration in undergraduate and graduate schooling, most experts I spoke with immediately entered the field. These people have not been deterred by the global conversation. Their values have driven them to continue these efforts. There is a shared understanding in Florida that while the threats to corals are numerous and often unyielding, coral restoration is an essential part of the solution to this crisis. Dr. Rob Brumbaugh, a coral restoration manager at TNC, shared that he "had colleagues say to [him], 'Why are we wasting our time restoring? We should just focus on conservation.' My answer to that is where? There's none left" (Brumbaugh, personal communication 2019). 


\section{Demographics}

Of the 20 individuals I interviewed, all identified as Caucasian and two experts additionally identified as Latinx. The average age of experts was 34 years old, with ages ranging from 25-54 years old. Some experts have been involved in coral restoration in Florida since its beginning and have thus worked in the field for over 20 years. Overall, the average length of time in the field was roughly 14 years. I interviewed 12 females and 8 males. $55 \%$ of experts had received a $\mathrm{PhD}$, while $20 \%$ had received a bachelor's and $25 \%$ a master's degree. Occupations of experts in this study varied, with individuals holding positions at state and federal agencies, nonprofit organizations, and academic institutions. However, most experts I interviewed worked at nonprofit organizations. The type of position they held within each organization also varied. Experts were scientists, managers, educators, and "other". Of the two individuals who held "other" positions, one worked in marketing and the other worked in policymaking (fig. 3a-d). Most of the experts I spoke with identified their role as a "coral restoration practitioner". 

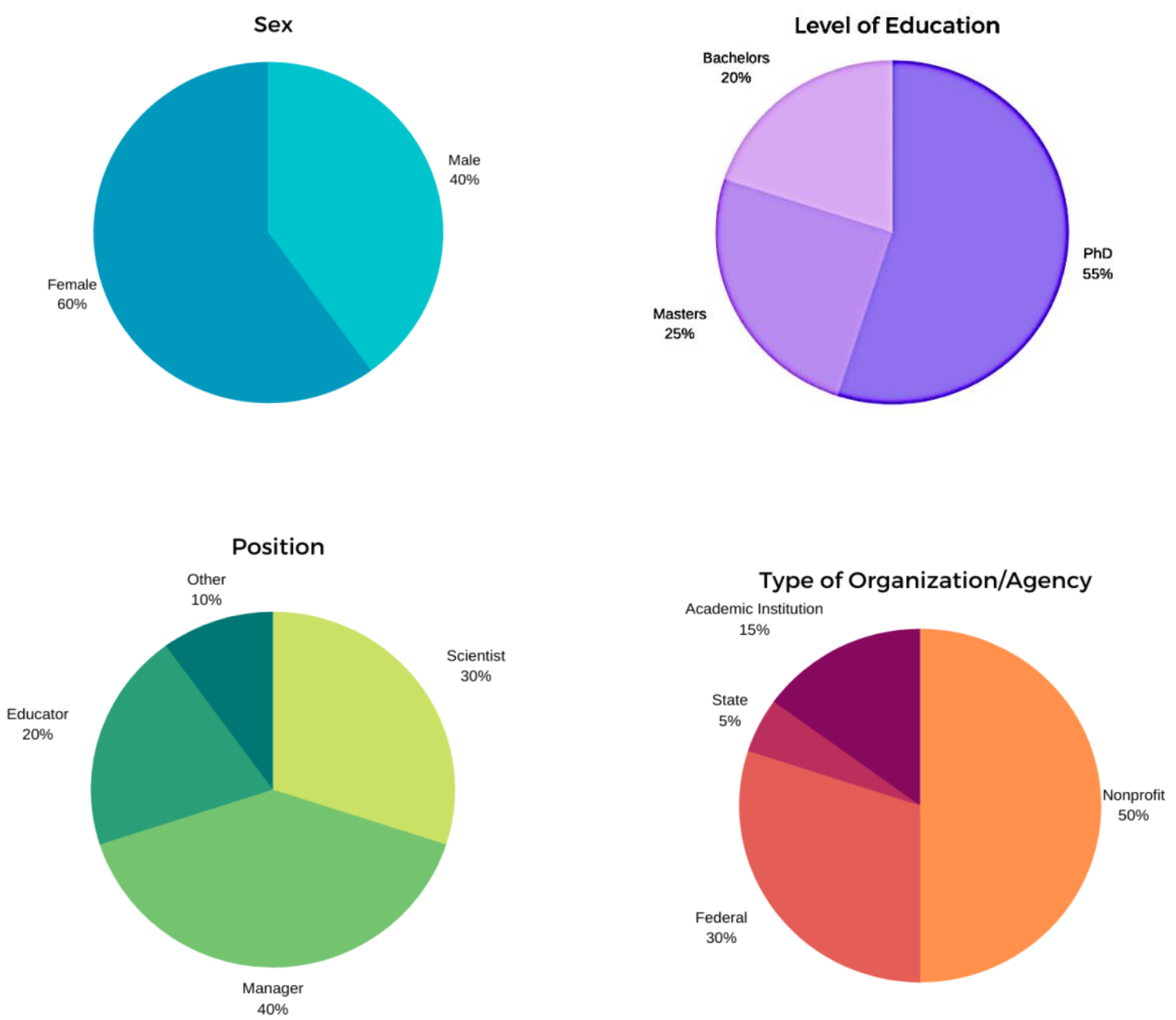

Figure 7: Pie graphs showing the demographics of Florida's coral restoration experts included in study (n=20). Variables included are "Sex" (blue), "Level of Education" (purple), "Position” (green), and "Type of Organization/Agency” (orange).

\section{Layout of Paper}

The following sections describe Florida's field of coral restoration in depth.

Particularly, section 2 delves into the history of U.S. coral reef management shows how coral restoration has emerged as a legitimate practice of coral conservation in Florida. Section 3 reveals the personal values of Florida's coral restoration experts. Section 4 details the types of coral-care in Florida and the impact of values on decision-making in 
the field. Finally, section 5 discusses experts' visions for the future of the world and Florida's coral reefs. 


\section{SECTION 2}

\section{How a Changing World has impacted Florida's Coral Reef Management}

Environmentalists' early accounts of the natural world have been told from the western, patriarchal, and capitalist human perspective. In this narrative, white, privileged patriarchs are the protagonists, attempting to dominate or master nature (Lorimer 2015; Haraway 2016). The way environmental storytellers envision the relationship between humans and nonhuman assemblages in the world has significant impacts on the chosen methods of environmental management. In the past century, traditional, western, and preservationist approaches to environmental protection, such as national parks or wilderness areas, have given way to more interventionist methods, such as ecological restoration. Present environmental management is a product of the Anthropocene, as scientists are attempting to use technological advances to reverse or lessen the impacts of anthropogenic climate change in order to save highly commodified or valuable species and ecosystems (Lorimer 2015). Many environmental management efforts today have struck a balance between preservation and restoration efforts; however, the efficacy of preservation to protect species from extractive or exploitative anthropogenic impacts has come under scrutiny in many scientific fields. For instance, many experts in the global coral community recognize that traditional methods of management will not stop the ongoing coral reef decline (Braverman 2018). Global climate change cannot be stopped using only marine protected areas, and because of this, some parts of the world have turned to coral restoration to save corals.

Florida is a unique environment to study the field of coral restoration because Florida has one of the largest coral reef tracts, has a long history of exploitation and 
threats to reefs, is an accurate representation of a reef in the Anthropocene (on the brink of collapse) (Jackson et al. 2014), and has a long history of regulation (traditional management) to protect corals. Coral restoration has emerged in Florida as a prominent management tool in the last twenty years. Florida's shift in coral management strategies, from heavily relying on marine protected areas to now also strongly emphasizing coral restoration efforts, can be used as a proxy for understanding the complex scientific challenges that arise in the Anthropocene more generally.

\section{"Traditional" Environmental Ideals}

The early $19_{\text {th }}$ century Transcendentalist movement laid the foundation for the traditional American ideals of environmental management. Following the teachings of transcendentalist philosophers, naturalists and environmental activists like John Muir began campaigning for the preservation of nature and wilderness (Cronon 1996).

Preservation is a form of protection that isolates marine or terrestrial areas in order to maintain an already existing state of nature. Historians argue that such preservationists viewed nature as static. The reasoning of the time held that by setting areas aside to remove the harmful impacts of environmental exploitation, nature's wildness can remain "pristine" and intact. This narrative defines wilderness as locations untouched by man and free of man's destructive capacity, and therefore worthy of protection (Cronon 1996). Activists during this era often disseminated romanticized views of nature through poetic letters and journal entries, employing biblical metaphors in their writing. John Muir once journaled, "In God's wildness lies the hope of the world - the great fresh unblighted, unredeemed wilderness. The galling harness of civilization drops off, and wounds heal 
ere we are aware" (Muir 1894, pg. 317). For him, nature's wildness was sublime and apart from civilization. In wild places, Muir believed one could find solace and heal from the wounds inflicted by humanity: i.e. the destruction of the world that came with advancing in industry and technology, and growing tourism. Early American environmentalists and naturalists saw the potential for industrialists and tourists to destroy the natural world, but believed that through preservation efforts, these areas could endure these extractive practices. William Cronon describes this perception of wilderness in the U.S.,

It is an island in the polluted sea of urban-industrial modernity, the one place we can turn for escape from our own too-muchness. Seen in this way, wilderness presents itself as the best antidote to our human selves, a refuge we must somehow recover if we hope to save the planet. As Henry David Thoreau once famously declared, "In Wildness is the preservation of the World." (Cronon 1996, pg. 1)

This philosophy instills nostalgia and passion for the romanticized nature of the past; a nature that existed during the times of great exploration prior to industrialism. Wilderness is seen as an escape from the real world; it is somewhere to journey to when urban life becomes overwhelming. To experience its wonder, one must have the capacity to travel to and explore these faraway lands. Historians and anthropologists argue that the early teachings of wilderness philosophers created a narrative that placed western males at the center of the collective world's story (Haraway 2016). In this story, all those that use these areas are the destroyers of God-given wilderness. Yet, cultural scholars have argued that wilderness is no more than a socially constructed perception of what nature should look and feel like. It is not an accurate representation of the world and it 
incorrectly confines nature to nonexistent pristine lands; for nature is not static, nor can it exist separately from humans regardless of their race, class, or gender (Cronon 1996; Haraway 2016). It is a constant eb and flow of life and death, of creation and destruction, of harvesting and regrowth in the physical world. The nature that exists today is different from a thousand years ago, and that nature is different from a million years ago. But different does not have to equal worse. New islands have formed from molten lava; existing islands have subsided under the seas. It is all part of the eb and flow. As other species leave their mark on the physical world, so too will we.

Beneath the layers of romantic and poetic language used to describe wilderness lies injustice. To believe that there exists lands or seas untouched by people is to ignore the vast histories of the world and indigenous peoples' that have occupied the land and sea for thousands of years. Wilderness philosophy is therefore colonial in its foundation promoting the removal of local and indigenous people from an environment, while also falsely emphasizing that these people and their cultures never existed in these places to begin with (Cronon 1996). Additionally, wilderness becomes inaccessible to those who cannot escape their daily lives, such as those tied to a place because of their work, the social structure in place, or finances, and implies that these people will never experience its wonder. It confers privilege to those who can experience it, and because of that, historically, it is rooted in elite whiteness in the American context. Additionally, trusting in and believing this wilderness philosophy gives environmental exploiters a "false hope of an escape from responsibility, the illusion that we can somehow wipe clean the slate of our past and return to the tabula rasa that supposedly existed before we began to leave our mark on the world" (Cronon 1996). The poetic writings and teachings of early 
philosophers and naturalists rely heavily on pathos to ignite a passion and desperation in many for wilderness that is lost or disappearing. These emotions, strong as they are, allow the false promise and hope of pristine wilderness to permeate environmental management decisions today.

\section{Anthropocene Environmental Management}

Wilderness philosophy and its emphasis on preservation has laid the foundation for the field of American environmental management. However, as the world entered the Anthropocene - the timing and definition of which vary among scientists and academics - a shift occurred in the way many envision the methods of environmental management. Two common responses to the Anthropocene have emerged within conservation: the first promotes mitigation tactics using advances in technology and geoengineering, whereas the other promotes a rewilding of nature (Lorimer 2015). While, the narrative environmentalists and conservationists now tell in the Anthropocene still presents extractive human practices, such as industry, tourism, and capitalism, as environment-destroying forces, this narrative has now expanded to include conservationists as the potential environment-saviors. Yet this narrative is again flawed: it perpetuates the belief that humans and nature exist in separate domains and is told only from the perspective of elite and privileged humans who continue to strive for dominance over nature and nonhuman life (Lorimer 2015; Haraway 2016). The underlying anthropocentric belief that nature can somehow be "fixed" or returned to some pristine state originates from early ideals of wilderness. Wilderness itself is highly contested today, yet many still strive for it. As Banu Subramaniam states, "[ghosts] are all sorts of 
dead ideas, and lifeless old beliefs, and so forth. They have no vitality, but they cling to us all the same, and we cannot shake them off' (Subramaniam 2014). Wilderness is a lifeless old belief, a ghost, yet it clings to many, and many still cling to it.

The ghosts of this wild past continue to infiltrate present day environmental management decisions. Sylvia Earle, a prominent figure in the field of marine biology, exemplifies this through her promotion of ocean preservation, stating,

What we've done here is identify a number of critical areas that represent a real hope to restore the health of our imperiled ocean. The pristine seas, the World Heritage areas, marine sanctuaries, marine protected areas, reserves - whatever they're called. We started with 19 , now the number is 50 but for me there really is just one Hope Spot - it's the ocean (IUCN 2019).

Her use of "pristine" is rooted in wilderness ideals and advocates for preservation or human-use restrictions. In this way, it perpetuates the belief that humans and nature should be separate in order for nature to be healthy.

Despite this, there has been a shift in this narrative that has paved the way for new environmental management methodologies to advance. Preservation efforts were the dominant form of environmental protection during the 19th century (Cronon 1996) and are still utilized today, but interventionist efforts began gaining momentum in the 20 th century (Cairns and Heckman 1996). These efforts go beyond implementing marine reserves and sanctuaries; they use expert scientists as tools or agents for environmental success (Braverman 2018). Instead of focusing efforts on the removal of people, human uses, and their impacts, interventionist efforts allow scientists to intervene in and facilitate biological processes to ensure species survival. Relying on techno-fixes and innovative thinking, interventionist methods allow scientists to be active participants in 
nature's processes (Braverman 2018). Interventionist methods focus on restoring ecosystems through methods such as genetically altering species' genomes to better suit them for survival; forcing or artificially inducing species' reproduction; collecting of species genetic information in gene banks to ensure their long-term survival. The outcome of such restoration projects depends on the goals of environmental managers. In times of disaster, managers may use restoration as a means to restore an environment or species back to its pre-disaster state or population size. Restoration can also be used to strengthen and enhance an existing habitat or ecosystem or introduce a species or ecosystem into an environment it has not previously existed in before (Cairns and Heckman 1996).

The ghosts of preservation are visible in some restoration efforts, as many environmentalists are still grappling with ways to turn back time and restore wilderness. Interventionist methods, such as active restoration, perpetuate anthropocentric ideals, and like preservation, these methods can be foundationally colonial (Parreñas 2018). While restoration continues to gain popularity in the 21 st century, there still exists a debate over the legitimacy of these efforts, most notable in the field of coral restoration. The symbol of the black box, described famously by Bruno Latour, works well here. A black box is closed when ideas are settled, when things run smoothly, and/or when something is considered successful (Latour 1987). The black box of coral restoration is open and in it lies not only a controversial global disagreement over how to save the world's remaining coral reefs, but also a near unanimous agreement that the world's coral reefs must be saved (Latour 1987; Braverman 2018). 


\section{Global Coral Restoration}

Due to advances in technology, increasing and continued threats to corals, and the perceived limited efficacy of preservation methods alone, the field of coral restoration has rapidly grown in the past decade. Peter Sale, a renowned coral scientist, stated in an interview with Irus Braverman, the author of Coral Whispers,

...most of the time we try to manage reefs by creating protected areas, and then we don't actually protect them. But if we assume that we get really good and we create protected areas and we really protect [corals], the reefs are still going to change, they're still going to degrade... Our protected areas do not protect against warming or acidification (Braverman 2018).

There is a recognition among scientists that traditional methods of management, i.e. preservation, are limited in their abilities. Thus, many scientists have turned to coral restoration as a product of the Anthropocene. The benefits of coral reefs are dispersed both locally and globally. Coral reefs provide coastal communities with shoreline protection and fisheries, while also offering a broader range of ecosystem services for local communities and beyond, such as habitat for important fisheries and breakthroughs in medicinal research (Moberg and Folk 1999). These services have been commodified and coral restoration, therefore, is a mode of protecting and enhancing these services and their monetary worth. It also coincides with a common response to the Anthropocene, as coral scientists are attempting to use technology and innovation to reverse or lessen the damage of anthropogenic stressors (Lorimer 2015). The looming threat of global coral extinction has forced many global leaders in the field of coral conservation to shift beyond preservation of reefs. They are now taking measures into their own hands to 
prevent the mass extinction of reefs. However, finding a solution to the coral crisis has sparked controversy among the coral scientist community.

Following the third global-bleaching event in 2017, Irus Braverman's book Coral Whisperers highlights the impassioned debate that exists between global coral scientists and identifies the impact of the hope vs. doom and gloom pendulum on management practices. From these differing perspectives come different methods for management, where hopeful scientists tend to favor techno-fixes more so than those of the doom and gloom perspective (Braverman 2018). In this global community, many scientists argue that the answer to the coral crisis lies in reducing local stressors and restoring corals. Coral restoration proponents see restoration as an opportunity to increase coral species diversity thereby strengthening their resiliency to threats (Braverman 2018). More so, restoration is simply a method for scientists to facilitate the health of coral reefs and actively do something for reefs; the alternative to this recourse implies there should be no active action on behalf of scientists, and that is something most coral restoration practitioners say they cannot do (Braverman 2018).

Contrarily, opponents of the field dispute these claims, arguing that the world must first mitigate global climate change (Braverman 2018). Leaders of the coral community who favor global action over local action see restoration as taking scarce resources away from climate change mitigation. Hough-Guldberg, a leading figure in this field, argues that scientists should first focus on reducing greenhouse gas emissions and preserving corals that are already genetically resilient to climate change (Braverman 2018). In fact, the many opponents of restoration that Braverman has interviewed believe that "restoration is a mistake [and is] a form of escapism" (Braverman 2018). From their 
perspective, restoration is a way for scientists and members of the coral community to avoid implementing the real systematic change necessary for climate change mitigation to occur.

\section{Florida's Legal History of Coral Protection and Policy}

Since the mid twentieth century, the U.S. has made efforts to federally mandate coral reef protection. Legal efforts first began as a way to preserve natural coral environments through restricting human uses but have since shifted to also include both coral preservation and restoration efforts. National legislation coupled with more recent local management strategies has set the stage for the field of coral conservation, and subsequently restoration, to emerge and advance in Florida. Florida's coral reef tract, extending from Dry Tortugas National Park to Martin County, is approximately 360 miles in length (Florida DEP 2019). National coral reef management legislation first focused on preservation practices, shown through the establishment of marine protected areas, but has since shifted to incorporate both restoration and preservation tactics.

Federal coral protection in Florida officially began with the designation of several marine sanctuaries in the mid 20th century, which culminated in the formation of the Florida Keys National Marine Sanctuary in 1990. The Florida Keys consist of a string of islands located off of the southern coast of Florida and encompass a major portion of Florida's reef tract. The FKNMS sanctuary designation has a brief but coral-centric history, dating back to the 1950s when environmentalists first became concerned with coral degradation in the Florida Keys. This concern led to the establishment of the John Pennekamp Coral Reef State Park in 1960, encompassing the Florida coral reef tract from 
Carysfort Reef to Molasses Reef (NOAA 2019). Due to escalating concern over the health of corals and other marine life, the following decade saw a boom in preservation sites, or marine protected areas, in the Florida Keys. In 1975, the Key Largo National Marine Sanctuary was created, and later in 1981 the Looe Key National Marine Sanctuary was established, each of which created human use-restrictions. However, while these two sanctuaries worked to reduce stress from extractive activities, several mass coral bleaching and widespread coral disease events continued throughout the ' $80 \mathrm{~s}$ and '90s (NOAA 2019). As concern for marine life was peaking, Florida's corals were once more threatened when the Keys were subjected to oil spills and run-aground ships. This led Congress to rapidly develop a plan for and designate the FKNMS in 1990 (NOAA 2019). The sanctuary borders 2,900 nautical miles of southern Florida Keys coastline, extending to Dry Tortugas National Park. The Florida Keys sanctuary designation was part of a national push for increased preservation areas and it is one of fifteen national marine sanctuaries in the U.S. (NOAA 2019).

During the same time, national legislation further pushed for coral protection in the U.S. coral reef areas. The 1972 Coastal Zone Management Act, Clean Water Act, and Marine Protection, Research, and Sanctuaries Act all included specific provisions for coral reef protection (Fox and Westfal 2018). Under the Coastal Zone Management Act, all federal projects must align with state coastal management plans. In areas where there are coral reefs, State plans must have special guidelines for coral reef safety. The Clean Water Act includes rules for dumping and discharges in particularly important marine areas, such as near coral reef ecosystems. The Marine Protection, Research, and Sanctuaries Act additionally deals with ocean dumping and requires U.S. vessels to 
choose a discharge site that avoids coral reef areas or other important breeding, spawning, and nursery areas (Fox and Westfal 2018).

The Magnuson-Stevens Fisheries and Management Conservation Act of 1976 continued the trend of federal coral protection. This Act established eight fisheries management councils (FMCs) throughout the U.S. EEZ waters. Florida, because of its location, is a member to two FMCs: The South Atlantic FMC (SAFMC) and The Gulf of Mexico FMC (GMFMC) (fig 4) (USFMC 2020).

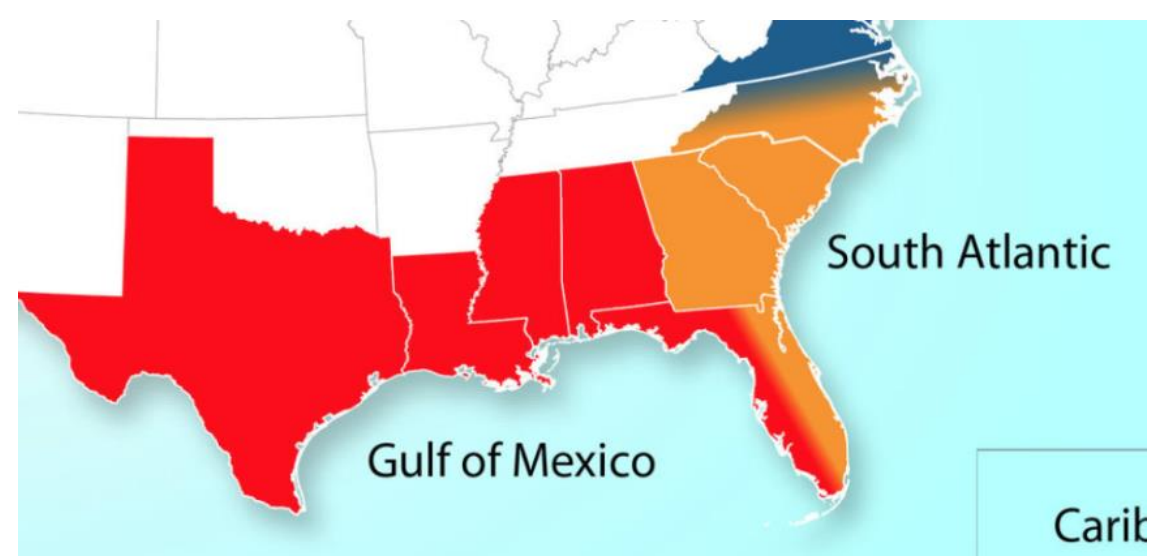

Figure 8: Map showing the jurisdiction of the South Atlantic Fishery Management Council (orange) and the Gulf of Mexico Fishery Management Council (red). Jurisdiction is split in Florida between the two councils (USFMC 2020).

In 1982, the SAFMC and GMFMC published a joint management plan for coral reef ecosystems within their jurisdiction. The coral management plan created protocols for coral harvesting, specifically prohibiting the harvesting of stony corals and sea fans within the Fishery Conservation Zone, also known as the Economic Exclusion Zone extending out to $200 \mathrm{~nm}$ from shore. This plan further set forth proposals to reduce impacts from consumptive activities and increase public knowledge about coral reefs (Gulf of Mexico and South Atlantic Fisheries Management Councils 1982). In 1996, 
Congress updated the Magnuson-Stevens Fisheries and Management Conservation Act of 1976 to acknowledge and call for the restoration of "Essential Fish Habitat Areas". Coral reefs were among the marine ecosystems considered essential for fish habitat, nurseries, and spawning grounds (“Essential Fish Habitat” 2019).

As coral protection was gaining momentum, Bill Clinton signed the executive order 13089 in 1998, which established the U.S. Coral Reef Task Force (CRTF). This action was intended to build upon previous legislation and create a unified approach among federal and local partners to coral protection (Exec. Order 1998). The CRTF was formed to increase coral reef ecosystem knowledge through mapping, monitoring, and research. It additionally aimed to discover ways to conserve coral reefs through reducing anthropogenic threats in U.S. waters. The task force initially focused on finding solutions to issues such as pollution and overfishing in order to promote sustainable interactions with coral reefs (USCRTF 2017). With the threats to corals continuing, the CRTF conceived the National Action Plan to Conserve Coral Reefs in 2000. This plan created 13 management strategies to address the coral crisis and included methods for building partnerships among national and local organizations. In 2002, the CRTF additionally drafted the U.S. Coral Reef Conservation Act to enforce a National Action Strategy to supplement the National Action Plan's efforts. The National Action Strategy called for the formation of NOAA's Coral Reef Conservation Program, which created a framework for collaborative coral protection in the U.S. Coral reef restoration was among the strategies proposed in both the national action plan and strategy.

Because of this, Florida's coral management strategies expanded during the late 90s to early 2000 s to involve more restorative methods. This shift in methods was a 
response to not only national legislation, but also an increase in the threats to corals and a decrease in the vitality of the Florida's reefs (personal communication 2019). Local legislation and management strategies supplemented national legislation to advance coral conservation and restoration efforts in Florida. Because reefs outside of the FKNMS lacked a coordinated management strategy, the CRTF, Florida DEP, and FWC established a Southeast Florida Coral Reef Initiative team to facilitate partnershipbuilding and address threats to corals reefs in Miami-Dade, Broward, Palm Beach, and Martin counties (Florida DEP 2020). This team developed a Local Action Strategy, which addresses six major issues: pollution, overfishing, recreational use (and misuse), climate change, coral bleaching, disease, and lack of public awareness. The plan further includes strategies and objectives for coral reef restoration (Collier n.d.).

As concern for Acropora coral species was peaking following the major disease event in the 80s that sparked their decline, NOAA in 2005 added elkhorn (Acropora palmata) and staghorn (Acropora cervicornis) corals to the Endangered Species Act of 1973. NOAA revisited the Acropora ruling in 2014 and reaffirmed elkhorn and staghorn's status as threatened ("Listing of Elkhorn" 2018). Prior to this in 2009, the Florida DEP enacted the Florida Coral Protection Act which authorizes the Florida DEP to enforce penalties when reefs are damaged due to anchoring, groundings, or other harmful vessel activities. Under this act, vessel owners are held accountable when harming reefs and must take action to help restore coral reef areas damaged ("Florida Coral Reef Protection Act” 2009).

The last decade has seen a continuation of efforts to protect corals, with emphasis on community-building and coral restoration. In 2010-2015, TNC's Florida Reef 
Resilience Program team, consisting of coral managers and reef users in South Florida, devised a Climate Action Plan which aims to unify what they view as Florida's fragmented coral management structure (Florida Reef Resilience Program 2010). As part of the program's efforts, the team formulated a Florida Reef Tract Coral Bleaching Response Plan to coordinate bleaching response efforts (Florida Reef Resilience Program 2013). Additionally, the FKNMS is undergoing a process to update and/or change sanctuary regulations and zones. In 2019 a FKNMS Restoration Blueprint was drafted, which discusses alternate management strategies to restore coral reefs, among other important marine life (Ross 2019). This ongoing process exemplifies the combination of restoration and preservation management strategies that have become common in FL.

Restoration efforts first began as a response to ship groundings on reefs and were focused on saving the already existing reefs. Tom Moore, the team lead for NOAA's coral restoration efforts, describes Florida's coral restoration field and how its purpose has changed over time:

We [first] thought about it as something for ship groundings and something to build awareness and stewardship. And then, as the 2000s started we started to get a better handle on the magnitude of the losses that were taking place, in particular with elkhorn and staghorn corals (the Acropora palmata and Acropora cervicornis), in the Caribbean. We realized the extent of the losses that we were facing from those corals as a result of a combination of bleaching and disease. We started to say, "We're going to need to do something about this" (Moore, personal communication 2019). 
As Moore states, coral rescue restoration efforts have expanded to include the growing and outplanting of new corals for population enhancement. Starting as smallscale pilot projects in the FKNMS, organizations began creating in situ coral nurseries to grow corals and develop methods for rebuilding Florida's coral reef tract. NOAA, in conjunction with the FWC, the National Park Service (NPS), the US Geological Survey (USGS), the Nature Conservancy (TNC), and other competent organizations, laid the foundation for restoration projects through monitoring, data collection, funding, and permit allocation for projects (personal communication 2019).

Local Key’s resident Ken Nedimyer and his grassroots efforts additionally played a pivotal role in the birth of Florida's coral restoration field. Ken Nedimyer, a then commercial fish collector and live rock farmer, established the Coral Restoration Foundation in 2007 (CRF 2019). Nedimyer's contributions began as mere happenstance in the 90s when endangered staghorn corals began growing on his live rock farm in the waters of Tavernier, Florida. A scientist himself, he began to think of how this could be useful. Motivated by a desire to keep and protect the corals, Nedimyer grew the corals and eventually, in 2007, established the foundation (CRF 2019). He has since established other organizations, such as Reef Renewal, that conduct restoration projects throughout the Caribbean (Reef Renewal 2019).

Throughout the past decade, the increasing availability of funding has increased the capacity of Florida organizations to conduct restoration. Coral restoration was once considered a more radical, and maybe ineffective, approach to coral reef management; 
however, it has now become normalized in Florida. Thus, coral restoration has emerged in Florida as a legitimate strategy for coral protection. 


\section{SECTION 3}

\section{The Values of Florida's Coral Restoration Experts}

A majority of coral restoration experts in Florida are dedicated to coral conservation and feel a hope "evinced by life in the Anthropocene" (Braverman 2018). These coral managers, scientists, restoration practitioners, and educators are attempting to save Florida's corals, but the extent and methods of restoration are not entirely transparent. What ecosystem state can withstand the challenges of the Anthropocene? How many corals are enough to meet the needs of society? How many corals are enough to sustain the marine life that rely on them? How many corals are enough for the health of the biosphere? Throughout my interviews, I aimed to explore the values of Florida's coral restoration experts and learn their definitions of a "healthy" reef in order to discover how the values held by experts influence this definition and the methods employed to save corals.

\section{Theoretical Framework for Understanding Values}

There is a dissonance in the way different disciplines define and use the term "values." I approached this research from an ethical social psychology standpoint and define values as relatively stable principles that guide our actions especially when there are conflicting preferences, or tradeoffs (Hitlin and Piliavin 2004; Dietz et al. 2005). A value is something that is fundamentally important to an individual and conveys a sense of what one thinks is "good" or "right". In social psychology, people are thought to have multiple hierarchical values. This means that some values are more important to individuals than others and they may be more salient in different contexts (Values 
researcher, personal communication 2020). In the social psychology literature, the Schwarts model identifies three value orientations pertinent to environmentalism. These orientations are "self-interest, altruism towards other humans, and altruism towards other species and the biosphere" (Stern et al. 1999; de Groot and Steg 2008; Dietz et al. 2005; Hitlin and Piliavin 2004).

Egoistic altruism is a self-enhancement orientation that represents things one values for the benefit of oneself. This is also referred to as self-interest. Egoistic altruism values are instrumental, meaning that they are things that are not valued for their own sake, but rather for a purpose of achieving some personal benefit. Social altruism is a self-transcendent orientation that represents things that one values or thinks is fundamentally important for the benefit of society. These values are also instrumental values because they provide benefits to society. Contrarily, the biospheric altruism orientation represents the intrinsic value of nature, meaning that the environment and its life forms are valued for their own sake or existence (de Groot and Steg 2008; Dietz et al. 2005). These value-orientations are not mutually exclusive as values can belong in more than one category. Understanding the underlying social psychological values of members within a given field is important because these values can influence an individual's beliefs, attitudes, and behaviors within their field (Hitlin and Piliavin 2004; Dietz et al. 2005), as discussed in the next section. Therefore, identifying Florida's restoration experts' values can help policymakers, the American public, and members of the global coral community understand why these experts have taken on this role and assess how their values influence decision-making in the coral restoration field.

\section{Experts Values}


Table 1: Values of experts $(n=20)$ found in each value orientation: social altruism, egoistic altruism, and biospheric altruism. Values are not ranked.

\begin{tabular}{|l|l|l|}
\hline Social Altruism & Egoistic Altruism & Biospheric Altruism \\
\hline Education & Leadership & Biodiversity \\
\hline Ecosystem Services & Active Response & Pristine Wilderness \\
\hline Ecological Research & Community & \multicolumn{2}{|}{} \\
\cline { 1 - 1 } Community & \multicolumn{2}{|l}{} \\
\cline { 1 - 2 } Leadership & \multicolumn{2}{|l}{}
\end{tabular}

\section{Egoistic Altruism}

Irus Braverman identified a dualism that exists in the global coral community that oscillates between hope and despair (Braverman 2018). Her work highlights the internal struggle of members within the community as they attempt to diagnose and cure the coral crisis. Braverman revealed through extensive qualitative research that members conducting coral restoration tend to be the most hopeful and proactive about the future of coral reefs. As Nancy Knowleton from the Smithsonian Institute stated in her interview with Braverman, "Bleaching is bad but giving up is worse" (Braverman 2018 pg. 35).

As I interviewed Florida's coral restoration experts, I began to notice a similar trend. Rather than buckling under the weight of global criticism, harrowing coral status reports, and slow (but steady) progress in the restoration field, most individuals retained hope and faith in their work (personal communication 2019). Many felt that succumbing to the dreadful predictions of the future hindered action. Responding to the criticism of the field, an expert scientist at an NGO in Florida stated that

"I do have hope. By nature, I'm not an optimistic person. I tend to be more pessimistic, but I'm doing what I'm doing because I do believe in it. I think it's important. Like as other people have said, we don't have the option to not do anything. We need to just continue to try to do as much as we can" (personal communication 2019). 
A majority of the individuals I spoke with felt a responsibility to act, and this action provided them with a personal satisfaction and relief that they were doing what they could to help. They did not want to be a bystander in the coral crisis and saw their active participation as a fundamentally important way to prepare and arm coral reefs for ongoing and future threats. Through this preparation and active involvement, Florida experts believe they can ensure coral reef survival. During our interview, Tom Moore described a conversation he had with researchers from the Smithsonian Institution. Using the giant panda crisis as a warning of what's to come if coral conservationists don't do restoration, the researchers urged Moore and others to "start earlier than you think you need to start on recovery... be more aggressive than you think you need to be...work faster, and...be willing to take more risks than you think you would normally be willing to take" (Moore, personal communication 2019). Because of this message, Moore has dedicated $20+$ years of his life to the mission of saving corals using restoration. Over the course of our interview, Moore expressed a sentiment shared by many experts: if we are not taking action, who will? What was revealed was not a strong conviction that restoration is not the solution to the crisis, but rather a commitment to trying multiple methods of conservation at once.

When discussing successes within the field, many individuals saw it as imperative that there are leaders in the field to be models for others. When I asked one expert scientist who their role models in the field are, they shared names of coral restoration experts in Florida who they consider the "pioneers of coral restoration," such as Ken Nedimyer and David Vaughan (personal communication 2019). Additionally, many of the experts in managerial positions self-identified as the current leaders in Florida coral 
restoration. They too viewed their role as the pioneers of the field and additionally valued community-building of restoration practitioners, managers, scientists, and educators. These individuals enjoyed being in a position of leadership and gained a sense of accomplishment from helping the field advance. A coral restoration manager at an NGO stated that,

"My role and also what I enjoy doing most is building our program here...in a way that not only are we able to make a difference here, but also we're able to take what we're learning here and share with other people, meet other people, learn other techniques, and build that knowledge around restoration" (personal communication 2019).

Throughout this interview, this expert expressed the personal benefit gained from their position. However, while the individuals that strongly valued leadership and identified themselves as leaders were motivated by self-interest, most were additionally motivated by the benefits their leadership could provide to society, as shown in the quote (personal communication 2019).

\section{Social Altruism}

Concerns for the welfare of current and future societies was a major motivator for Florida restoration experts. The potential to sustain the economic incentives of coral reefs strongly influenced many to join this field. For instance, nearly all experts valued ecosystem services and felt them critically important for supporting the current state of societal life. A lead coral restoration scientist at a research institution in Florida stated, "[What I am] focused on is getting [coral reefs] to a functional state so that they can still provide economic, environmental, and functional services" (personal communication 
2019). When specifically discussing coral reefs, important ecosystem services individuals most commonly identified were food, shoreline protection, and revenue from tourism.

Most experts also highly valued ecological research and felt it was necessary for creating innovative solutions in times of environmental crises. In relation to the coral restoration field, these experts viewed ecological research as a way to advance the field, leading to the survival of reefs and thus sustainability of ecosystem services. Experts valuing science did not exclusively occupy scientist positions. Those in management positions shared that their decisions are and should be guided by the best available science.

Some experts, most of which were in managerial positions, placed a high value on community, both within and outside of the global coral restoration field. Within the community, experts expressed an appreciation of information sharing between managers, scientists, practitioners, and educators to increase communication and collaboration in order for the field to collectively grow. One way this has been achieved is through the Coral Restoration Consortium (CRC), which NOAA and CRF co-manage. Moore, one of CRC's founders, described the network as "a global community of practice, where everybody working in the field of reef restoration is included, from practitioners to scientists, to managers, to educators."

While efforts to increase information sharing within the coral restoration community are increasing, outside of the field most experts viewed American public education and awareness of the coral crisis as lacking. Throughout our interviews, experts recounted tales of their encounters with Florida residents and tourists alike that were unaware of the threats to corals, including Florida's ongoing Stony Coral Tissue Loss 
Disease event. For instance, one expert, venting their frustrations, shared that tourists and local Florida Keys residents incorrectly believe that the biggest threat to coral reefs is sunscreen.

Several experts believe that from this lack of knowledge stems a lack of action. For self-described action-takers, this can be frustrating. Experts in all roles stressed the importance of educating people to create the systemic change necessary to save corals. That is, in order to change people's behaviors, experts emphasized the essential role of education to create an informed and environmentally conscious society concerned with saving coral reefs.

Articulating this, a coral restoration educator stated that "the only way that you can get people to change their minds is to educate them" (personal communication 2019). Because the coral reef ecosystem is not visible unless one is snorkeling or scuba diving, it is difficult to relate to or see the impacts of anthropogenic threats. Experts valuing education see the purpose of coral restoration, in addition to population enhancement, as being a way for the American public to interact with the reef environment and increase their knowledge about threats to corals through citizen science projects and volunteer opportunities.

\section{Biospheric Altruism}

In addition to valuing the services coral reef ecosystems provide, many experts were concerned with the health of the biosphere. They placed a high value on the existence of corals for the health of the ecosystem and species reliant on coral reefs. Because of this, maintaining the genotypic diversity of coral species is a priority for 
many restoration experts operating in Florida. In one of my interviews, a restoration manager working for an NGO stated that "[the NGO is] a big proponent of pushing the need for diversity to promote resilience on reefs, because you never know what that extreme event is and what it's going to take out" (personal communication 2019). This quote exemplifies both a valuation of diversity as well as of preparedness.

Lastly, some experts valued "pristine wilderness," or the existence of nature separate from anthropogenic impacts. Expressing this value, a coral restoration manager for a federal agency stated that "I think we should be looking more towards what the corals were back in the 60 s and 70s before they really started to decline" (personal communication 2019). This person valued the existence and vitality of Florida's reef before humans were thought to have caused major impacts. This value, among others, greatly impacts how experts define a healthy coral reef ecosystem.

\section{"Healthy" Coral Reefs}

My interviews revealed that there is disagreement and sometimes confusion over the way Florida experts envision and describe a healthy or ideal coral reef ecosystem. Many experts were stumped when I asked them how much coral we should restore, and one individual stated "[they have] been in several day workshops where [they] couldn't answer that question" (personal communication 2019). Because of this lack of clarity, experts communicated multiple definitions. Almost all experts stated that a healthy Florida coral reef is a genotypically diverse reef that is resilient to ongoing and future threats. This was a top priority and major concern for the experts and additionally the organizations they work for. 
Yet, the extent of the coral cover necessary to achieve a healthy reef ecosystem state was not unanimously agreed upon. For some experts, the ideal coral cover exists only in memory. The reefs of the past, thriving as they were, can never be restored. Rather, the future of coral reefs depends on innovation and technological advances, especially in the field of coral restoration. This hopeful and perhaps realistic approach to coral restoration places emphasis on restoring just enough coral to maintain ecosystem services. However, not all experts shared this economic approach to coral conservation. When asked what state we should restore reefs to, experts that valued pristine wilderness described a healthy reef as one that returns to the iconic time of the 1960s/70s. In Florida, this era signifies to them a time period when coral reefs were thought to have flourished and been majorly unaffected by anthropogenic threats. Because it was around the time that scientific studies began, this baseline research has been the basis for the perceived health of this era (Jackson et al. 2014; Toths 2018). Famous conservationists like Sylvia Earle have documented and described the declining Florida reef since the 70s, and instilled feelings of nostalgia in younger generations for these reefs lost (Jackson et al. 2014). Oral tradition plays an equal role in how people define healthy ecosystems. Because everyone I spoke with would have been either a child or not yet born during this time period, many rely on both the science and the personal stories shared with them over the years about the health of Florida's reef tract over time (personal communication 2019).

Social psychological values play a role in both how experts define a healthy reef ecosystem and also how they choose or advocate for forms of coral-care. More so, values help guide decision-making and goal setting in coral restoration. Because of this, it is 
important to make values transparent both within the field and beyond. The lack of consensus among experts over the definition of a healthy reef can result in additional growing pains for the field and can influence the methods of coral conservation. In the next section, I describe the forms of coral protection and outline the relationship between values and goals. 


\section{SECTION 4:}

\section{Care-Ful Conservation: How Values Influence Coral-Care in Florida}

"We are implicated in animals' lives and deaths, and they in ours. The ways humans participate and intervene in environments transcend an axiological standpoint: even measures designed to respond against the Anthropocene can, in fact, expand its reach." (Bocci 2017 pg. 427-8)

From 2001-2006, partnering organizations in the Galapagos Islands worked to eradicate goats, an invasive mammal that was threatening the life of endemic and endangered Galapagos tortoises and plants (Bocci 2017). The eradication process consisted of technological solutions, such as tracking goats and altering the sexual reproductive organs of female goats, and it resulted in the death of over $90 \%$ of goats on the islands (Bocci 2017). However, goats remain (albeit fewer in numbers) because the partnering organizations managing this project failed to consider the ecological and social role of goats in the Galapagos. Because of this, their efforts have not led to the intended outcomes. People living on the Galapagos islands continue to care for goats and have made a place for them in their lives; this has contradicted the project's efforts to save tortoises (Bocci 2017).

Throughout his tale of violent acts directed towards goats to save the loved and charismatic tortoises, Paolo Bocci challenges conservationists to contemplate their goals and intended methods of conservation. He argues that the end does not justify a violent means. Forms of care in the Anthropocene, or the actions taken to protect a species, while intended to save, are not always benign, and efforts to change the composition of the natural world will result in consequences. As global marine and terrestrial life forms are 
experiencing the impacts of anthropogenic threats, which life forms should we prioritize saving? How do conservationists decide what to care for, and from that, how do they decide how to care for it?

Especially in a time of crisis, it is important for experts in Florida's coral restoration field to reflect on why they are making decisions, because as shown in the Galapagos, "taking care" of chosen life forms can result in unintended and lasting ecological, social, and economic consequences (Bocci 2017). Like the endemic tortoises, coral reefs ecosystems are highly threatened, but how far should we go to save them? "Tangles of Care" serves as a meaningful reminder of the impact our actions can have when we act in urgency, when we attempt to dominate nature, and when we fail to consider the implications of our actions. This chapter will delve into the relationship between experts' values and their goals to show the influence values can have in coral conservation fields.

\section{Values \& Decision-Making}

Multiple factors influence decision-making and individual behavior. These factors are context dependent, but can include values, social norms, beliefs, and economic constraints. Values express our motivations to achieve certain goals (Hitlin and Piliavin 2004; de Groot 2008). Within the field of social psychology, there is empirical evidence that values influence behaviors and play a role in decision-making (Dietz et al. 2005). This role, either direct or indirect, is more influential in certain contexts. Researchers argue that values are most often invoked when there are tradeoffs or competing preferences, and/or in situations when people have time to reflect on their values before 
making decisions. Additionally, values have been shown to influence job selection and career path and may affect how one defines their role. How one defines their role can further influence their preferences (Dietz et al. 2005; Hitlin and Piliavin 2004; de Groot 2008).

People have multiple preferences or ideal outcomes for any given situation (Dietz et al. 2005). Individuals apply weight or assign a ranking to these preferences. Values influence the weight one applies to each preference. This ranking is then employed in the decision-making process. Because values are hierarchical and some may be more salient in different contexts, the assigned weight is context dependent (Dietz et al. 2005; Hittlin and Piliavin 2004). While in some situations other factors can override the influence of values, Dietz et al. 2005 states that, "values [are typically thought to] influence individual decisions and...individual decisions are consequential in shaping individual, and ultimately group, behavior with regard to the environment."

Overall, our choices are an amalgamation of all the different factors operating in a given context. Values are just one factor but they are an important aspect to consider, especially in the field of restoration ecology. While nearly every expert I spoke with in Florida emphasized that they use science to guide decision-making, restoration goals are both a reflection of ecological science and individual or societal preference for the future state of Florida's coral reefs. Because of this, restoration project planning is highly subjective (Davis and Slobodkin 2004; Hobbs 2002; Choi 2004; Choi 2007) and values may play a large role in this field, thus influencing the form of care chosen. Other important factors that can guide decision-making in Florida are the availability of funding and existence (or lack thereof) of political and public support (personal communication 
2019). While understanding the role of values only offers a partial glimpse into the decision-making rationality, identifying the underlying motivations in this field can help illuminate why Florida's coral restoration experts, in order to achieve their perceived "healthy" reef ecosystem, advocate for certain solutions over others.

\section{The Trinity of Coral-Care}

Because of the many economic benefits they provide, coral reefs have been chosen as an important life form that requires care in Florida. Under the current U.S. and Florida legal framework for coral management as outlined in Section 2, partnering organizations_-such as NOAA, TNC, NOVA Southeastern University, Mote Marine Laboratory, and others - lead coral reef conservation efforts in Florida. These organizations have identified and presently engage in three primary forms of coral-care: coral and water quality monitoring, coral reef ecological research, and coral restoration. These three forms of coral-care are conducted through several programs, such as (but not limited to) NOAA's Coral Reef Conservation Program (CRCP), TNC's Florida Reef

Resilience Program, Florida's Department of Environmental Protection's CCRP, and Friends of our Florida Reefs citizen-based efforts (Florida DEP 2020). This trinity of care consists of methods that build off one another and are often conducted in tandem, creating a mutualistic relationship between Florida's forms of coral-care. 


\section{Relationship Between Goals \& Values}

\section{Sympathetic Values and Goals}

All experts I interviewed identified one clear overarching goal of their work: restore coral populations on the Florida reef tract. Yet most individuals had more immediate and specific short-term goals to help achieve this long-term goal. Among these goals, experts prioritized educating people, leading restoration efforts, restoring biodiversity, and returning to a healthy ecosystem. Those that strongly valued education saw their role as an educator and wanted to focus efforts on increasing public education of the coral crisis in order to end threats to corals and create systemic change. Those who strongly valued ecological research saw their role as a scientist tasked with advancing the field through research and discovery. For instance, one lead scientist at a federal lab stated that their goal is "to understand how we can both increase the efficiency and efficacy of...restoration efforts, whether that be identifying methods or helping to understand what will lead to success in the field" (personal communication 2019).

The value of leadership was additionally present in many short-term goals. Those that value and define themselves as leaders stated that they want to establish demonstration sites, or sites where restoration efforts are consolidated, to be a model for successful restoration. A coral restoration manager shared that because "The Florida Keys are extremely degraded, [They] hope to be that example of restoration success." Leaders additionally expressed a strong interest in scaling-up restoration, where many are focusing their remaining efforts on creating a more unified and robust approach to coral restoration. One coral manager and educator, having been in the field for $20+$ years, discussed his goals for the remainder of his career: 
“...all of Florida will need a restoration blueprint--a plan [stating] the right mix of the right species at the right scale and density that matter...I'm focused on making sure that we get this kind of knowledge applied so that we're taking action at the scale that's going to ensure that we have a coral reef that is better when I retire than when I first started working for [in] Florida" (personal communication 2019).

While scaling-up restoration efforts was a major theme throughout my interviews, genetic diversity was equally if not more commonly mentioned. Most individuals and organizations in Florida placed a high value on biodiversity of corals. As a result, their objectives included outplanting genetically diverse corals onto reefs and increasing evolutionary ecology research to help restore reef diversity. An expert coral scientist at a nonprofit who works to increase coral diversity in Florida strongly supported efforts to engineer evolution, or induced sexual reproduction, because "through sexual reproduction, you get genetic diversity. You get the next generation. You get increased adaptive potential. You can get an evolutionary response. Without that, corals are not going to persist in the future" (personal communication 2019). This individual believed in restoration, but only if we can manage to create corals that are resilient to threats and genetically diverse from current populations. If Florida were to outplant only genetically similar corals, any disease or disturbance event could result in mass mortality.

Because people can have multiple values, it is possible for someone to value and support education efforts in addition to scaling-up efforts, and many experts did value and want to achieve both. However, some values were competing and resulted in opposing goals. It is important to identify values in relation to stated goals to determine 
not only which values are overlapping or competing, but also to determine how they influence the decision-making process.

\section{Competing Values \& Goals}

My interviews revealed that the preference for prioritizing ecosystem services vs. restoring pristine wilderness were competing values influencing goal setting in Florida's coral restoration field. Many experts weighted the instrumental value of ecosystem services and the intrinsic value of pristine wilderness differently. This then impacted how these experts defined an ideal or healthy ecosystem. Those who valued pristine wilderness advocated for returning reefs to the 1960/70s era. The ghosts of this pristine past serve to haunt today's efforts by becoming a baseline for many. This baseline is more than a representation of the science. While studies show that anthropogenic coral reef decline began in the 1970s in Florida, experts referred to more than the data when describing their baselines. Many used the word "pristine" to emphasize the perceived higher quality of reefs during this time. Others told stories. One expert shared that the 1970s was their goal because their friend once told them that "back in the day, you could tell you were near a reef when the water looked yellow" (personal communication 2019). Staghorn corals, not yet endangered, were so abundant that the color of the water reflected their health. Stories like these have motivated people in the field to strive for this baseline of pristine, untouched by man wilderness.

Yet there are still experts who have escaped this thread of thinking, or who have recognized that the world only moves in one direction: forward. I found that those who strongly valued ecosystem services defined their goal as restoring or sustaining functional 
reefs that maintain all the ecosystems services deemed necessary for society, oneself, or the environment. Food, tourism revenue, and shoreline protection were the most cited important ecosystem services in Florida. The baseline reef to return to here is one that can be self-sufficient in providing these services.

While some experts recognized this disagreement in goals, others appeared to be unaware. For instance, as described above, one expert scientist believes that "[the Florida coral restoration community] should be looking more towards what the corals were back in the 60 s and 70s before they really started to decline" (personal communication 2019). Another expert working at an academic institution stated that "that's still our target...to recover...to 30, 40 years ago" (personal communication 2019). However, while some are striving to achieve Florida's thriving reefs of the past, others are uncertain of this possibility.

Another coral restoration manager admitted that "in a lot of places [in Florida] we will not be able to get reefs to the point that they were 40 years ago when we had very high coral cover" (personal communication 2019). Another discounted the idea of returning to the past, stating "I don't think anyone believes that we will be able to restore reefs to the historical, pristine state" (personal communication 2019). These quotes show a misunderstanding pervasive in Florida's coral restoration expert community. These contradicting visions for the future exemplify two of the many challenges that come with conservation in the Anthropocene, as experts must act in times of uncertainty and shifting baselines. The issue of competing baselines can further reduce the cohesiveness of the field, something already at risk with the constant global criticism. 
Because these people are experts in the field, their voices matter. Their positioning allows them to make decisions at a multi-lateral scale and influence action in Florida and beyond. Values and goals and the connections between them that influence the form that coral care can take are important for gaining an understanding of the direction coral-care in FL. In an ever-changing world, we must reflect on the life forms we have chosen to protect, the way we have chosen to care for them, and why they have been chosen. 


\section{SECTION 5}

\section{Conclusion: Envisioning Coral Reef Futures}

The black box of coral restoration remains open. Inside this box lies many challenges to success. Florida's coral restoration field is experiencing what experts call "growing pains," and as the field attempts to advance, there are some obstacles in its way, such as the existing colonial Anthropocene narrative, where conservationists have a perceived ability to dominate nature, while people partaking in consumptive and nonconsumptive uses of the environment are the perceived destroyers of nature; a lack of public awareness and political support of the coral crisis; inadequate funding for restoration; and shifting coral baselines. These challenges are not unique to the field of coral restoration, but rather can be used as a proxy for understanding the challenges and stakes key conservationists face on the front lines of conservation in the Anthropocene, the ways in which the values that underpin conservation can be controversial, and the social political, and scientific challenges that environmental and marine scientists, educators, and managers are facing in a rapidly changing and uncertain world. As the coral restoration field rapidly grows, now is the time to reflect on the future that experts envision for reefs and the types of coral-care provided in Florida. Returning to the tale of the Galapagos once more, Bocci urges conservationists to change the narrative and move towards practices of care for the more-than-human, stating that "attention to care helps scholars and practitioners alike move past the rigid determination of success or failure for conservation measures toward an open, continuous commitment to the flourishing of multispecies life in the uncertain times of the Anthropocene" (Bocci 2017; 443). 


\section{Changing the Anthropocene Narrative}

Florida's coral reef tract is a reef in the Anthropocene, i.e. on the brink of collapse due to anthropogenic stressors. Responses to this epoch in Florida have led to shifts in coral management strategies over time. The emergence of coral restoration as a legitimate tool to save corals provides a unique opportunity to study conservation strategies in the Anthropocene. The way marine and environmental managers, scientists, and educators envision their relationship with nature, and how they tell the story of the collective world, influences environmental management decisions. One common response to the Anthropocene, faith in technological fixes to reverse or lessen impacts of climate change, has resulted in the emergence of the field of coral restoration. Yet, this field still tells the story of corals from the perspective of elite whiteness and capitalist ideals. Coral reefs have gone extinct many times; there is little doubt that if they were to again disappear, they would return in a later century or geological time period. As Rob Brumbaugh, a coral restoration manager at TNC, puts it "Reefs have been around a lot longer than people. Taking the very long view, there will be reefs" (Brumbaugh, personal communication 2019). However, coral reef ecosystem services provide valuable resources to both coastal and non-coastal communities. Therefore, members of the coral community in Florida have chosen to not let them disappear. While coral restoration allows restoration practitioners, scientists, managers, and educators to be active participants in the survival of coral reefs, coral restoration perpetuates wilderness ideals and the perceived divide between nature and humans. Additionally, restoration practitioners and restoration practices have the potential to be motivated by a desire to 
master or dominate the natural world (Lorimer 2015; Haraway 2016). Removing this divide is challenging because it requires people in these positions to reimagine a world where science is explicitly and publicly value-laden and all human and non-human assemblages are intentionally intertwined. Rethinking these roles within current social systems is challenging in and of itself and may require a departure from the current Anthropocene narrative (Lorimer 2015; Haraway 2016).

\section{Envisioning Coral Futures}

I again noticed Braverman's hope vs. despair pendulum when Florida's experts shared with me their outlook on the future of coral ecosystems in Florida and beyond. Many individuals in their answers swung from optimism about the future, to pessimism about the capabilities of restoration amidst persevering coral threats. While experts' predictions varied, there was a near unanimous agreement that the reefs of the future will be different from the reefs of today, just as the reefs of today are different from those of the past. Experts believe that coral cover and biodiversity will decline and some areas of the world will no longer have living coral reefs (personal communication 2019). They expect this to occur over the next century as climate change and other stressors continue.

There was additionally a consensus that restoration is in some way having an impact, either by achieving small-scale population-enhancement, or increasing awareness and education. However, many experts hoped that the scale of this impact will become larger and more meaningful in the future. There were numerous additional hopes for the future that experts revealed during our interviews. One coral restoration manager shared, "I wouldn't have come into the office today if there wasn't going to be a better future" 
(personal communication 2019). Some of these hopes included an increased public awareness and better communication of the coral crisis, new technological and research discoveries to better restoration practice, and a more unified management structure in Florida (personal communication 2019). Relating to awareness, a coral restoration manager at an NGO, recognizing the limitations of restoration, wanted these limitations to be clearly articulated in the future. This person stated,

"I think restoration oftentimes is looked at as the solution. We don't have to care about climate change because for any coral that dies, restoration is going to put it back. But it doesn't work that way. One of things that people hopefully start to understand is restoration isn't your catch all to fix everything that you've broken. You still have to fix the causes that got us here" (personal communication 2019).

Like this expert, many others understood that more than just coral restoration is needed in the future. However, some still held a strong faith in science and remained optimistic that Florida's reef tract will be fully restored. That being said, most individuals maintained a realistic attitude and acknowledged the challenges they face in Florida. Even those that felt Florida's reefs could be entirely restored, admitted that this feat might take many decades or even many lifetimes to achieve. Yet instead of letting this uphill battle discourage them, many have taken on the mindset that "we can only go up from here" (personal communication 2019).

\section{Florida's Coral Restoration "Growing Pains"}

During my interviews, coral experts in Florida provided me my own glimpse into Florida's coral management and the ever-changing and open black box of coral restoration (Latour 1987). Rather than a clear bifurcation between proponents' and 
opponents' views of coral restoration, I began to see a spectrum. On one end exists the argument that coral restoration, genetic modification, and technological advancements will undoubtedly save the reefs; on the other end exists the argument that coral reefs will only survive once climate change is mitigated. Many of Florida's experts land in the middle of this spectrum. As previously shown, most did not believe that restoration is the answer to saving the reefs; rather, they saw it as part of the answer, where the other parts consist of actions like climate change mitigation and local threat mitigation (personal interviews 2019).

Coral restoration has become a way for Florida's coral protectors to "buy-time" until climate change has been mitigated and/or other local stressors are reduced. As one coral restoration manager and practitioner states, "Global impacts need to have a global change. While that change takes place, we will do the very best we can to try to arm these corals with the ability to survive" (personal communication 2019). Florida's reefs have been degrading for decades, and as the reef continues to degrade, most experts see their action as the only thing standing in the way of total reef mortality. However, while many view this mitigation as necessary, it is unclear whose job it is to take on this challenge. Tom Moore, NOAA's coral restoration team lead, sees his efforts as separate from climate change mitigation. In our interview, Moore stated,

"I don't fundamentally believe that the plight of coral reefs will be what ultimately gets policymakers to wake up and change their mind about addressing climate change. I'm not worried about diluting the message in the coral reef community because I think that there are enough other things out there that are going to be what forces that action" (Moore 2019). 
His belief that reefs have been and will be unable to strongly influence national and global policy demonstrates that while coral reefs can garner some public interest in and support for protective efforts, climate change is less inviting and more likely to experience a political blockade. Yet, many experts were quick to acknowledge that systemic change is required to save coral reefs. When asked to identify barriers to ending threats to corals in Florida, experts most often stated a lack of political will throughout Florida and the U.S. Quick political turnover creates short time horizons and can sometimes force scientists, managers, and educators to act in ways that secure funding and are in the interest of the state. More so, short time horizons can encourage politicians to advocate for policies that will help them get re-elected.

When discussing specific policies that experts would like to see enacted, there were several recurring themes: improving water quality, restricting tourism, and including coral restoration in sanctuary management plans. Experts cited other parts of the world, particularly Australia's Great Barrier Reef Marine Park, when giving examples of possible legislation that could be introduced in Florida. One specific example that I heard from multiple people involved rezoning the FKNMS to remove or limit the number of tourists allowed in a given area. One expert shared that some areas of the FKNMS that are used for coral restoration are additionally open to recreational boating, snorkeling, and diving. To improve monitoring and measurements of restoration success, the individual called for the closure of these areas to restoration practices only. However, while most experts strongly advocated for more environmental policy in Florida, many were uncertain how easily these policies could be implemented due to the lack of political will. 
Political will is, ideally, influenced by the will of the public. Yet while the public is often quick to support the survival of charismatic, flagship species, people are slow to support the survival of other non-charismatic species (Lorimer 2015). Therefore, in a time that is often cited by the media as the 6th mass extinction event (Drake 2015; Bradshaw and Saltre 2019; Woodward 2019) global conservationists are challenged to find innovative ways to engage the public in caring for less attractive, appealing, or visible species. Although corals are often thought of as charismatic megafauna that draw public attention, because of their underwater and therefore not easily accessible location, experts in Florida's coral restoration field are too experiencing this challenge.

Based on my interviews, the phenomenon of shifting coral baselines has created disagreement or confusion not only within Florida's expert community over which baseline they should restore reefs to, but also between Florida's coral community and the public. A coral restoration scientist shared with me that "The Keys have some of the worst coral reefs in the world, but there are lots of fish and so people continue to go and be happy with their experience" (personal communication 2019). Many experts stated that they did not believe the public was aware of all the threats impacting corals, nor were they helping to garner political support for coral protection, which they likened to the location of corals (personal communication 2019). This is likely a result of the public oftentimes noticing the benefits of coral ecosystem services subtly rather than explicitly.

From the perceived lack of public support, and as a result of short time horizons, experts further perceive funding as lacking. Many admit that funding has increased over the past two decades, but that to achieve large-scale restoration success, more investment is necessary. Experts attribute the lack of funding to the lack of public and political 
support. They argue that to fulfill the potential of coral restoration, all three of these challenges must be addressed.

\section{Living with Uncertainty in the Anthropocene}

The current colonial narrative of nature in the Anthropocene allows conservationists to be the deciders of what lives and dies. As the holders of nature's fate within this framework, conservationists must make difficult decisions as to what endures and what succumbs to extinction in these times. Yet, the role of the conservationist is constantly being challenged in the Anthropocene. Beyond choosing which species and ecosystems are important or of value, scientists must also choose the forms of care necessary for their survival. The Anthropocene narrative is a story of forced tradeoffs. Conservationists must choose a method for species survival, yet in doing so they might forfeit other methods or forms of life. Values, amongst other factors, play a role in which method of care a conservationist will favor. As shown through the example of coral restoration, these decisions are often controversial.

In times of uncertainty it is difficult to make important decisions. Uncertainty can create a lack of local or global consensus and result in less unified efforts of protection, a reality that is exemplified in the field of coral restoration. The future is unpredictable and thus requires conservationists to be adaptable and to use natural and social science to guide their decisions. Florida's coral restoration experts grapple with uncertainty every time they envision the future of Florida's reef. They hope for the best, are realistic about their capabilities, but ultimately do not know what the future holds. The common theme present during my interviews was that reefs will survive. Whether we stop climate 
change, or corals learn to adapt to the stress, they will persist. Yet as Haraway's

Tentacular Thinking reminds us, we must not get caught up in believing that some safer future exists for the organisms we are trying to save. Rather than that, we must "stay with the trouble" and be capable of response no matter what (Haraway 2016).

The infusion of emotion and urgency in science is becoming more apparent in the Anthropocene but is not novel. It has existed since the days of John Muir and his campaigns for wilderness preservation (Cronon 1996). Because of this, Anthropocene conservation management has a level of subjectivity that is not readily acknowledged by those in conservation fields. This understanding can be challenging for conservationists to acknowledge, as management in environmental fields is advertised as being based on the best available science, which is assumed to be based on objective facts and knowledge. How conservationists redefine their role can have major impacts on policy and management. For example, climate change has permanently altered all of the world's living and nonliving assemblages, yet whose job is it to fix this? Re-envisioning the role of those in conservation fields may require a transition from the Anthropocene into some other epoch that values all life and tries to provide forms of care not based on capital and investments. This will allow us to work collaboratively and rewrite the anthropocentric narrative to better represent the multiple and mutualistic relationships between human and nonhuman assemblages.

When imagining the world and its entire geological history, humans, while capable of leaving a lasting imprint, are not the main actors of the story. That does not mean that we should become complacent with our actions or remove ourselves from the responsibility of action; rather, it is a reminder that even in the presence of an evolving 
environment, life (human and nonhuman) goes on, as it has, and as it will. We are part of the eb and flow. We should work to transition into an epoch to allow us to work collaboratively, provide multispecies care, stay with the trouble, and live with and die with each other in these times (Haraway 2016; Bocci 2017).

\section{The Challenges of Coral Science}

I found there to be a qualitative relationship between Florida's coral restoration experts' values and goals. While some of these overlapped, ecosystem services and pristine wilderness proved to be competing values that have resulted in competing goals in the field, contributing to the fields "growing pains" and perpetuating wilderness ideals. Because of this, there is a need for greater transparency of values and the decisionmaking process in Florida's coral restoration field. Florida's coral restoration scientists, educators, and managers influence decision-making at multiple levels (local, regional, and national). As the field continues to advance, now is an important time these leaders in coral restoration to reflect on their values and why they make decisions to limit future unintended consequence.

Overall, the shift in Florida's coral management strategies from preservation to restoration offers a tangible example of the common responses to the Anthropocene and the challenges the epoch creates. However, the challenges coral scientists face are not exclusive to them and can be applied to and felt by scientists in other fields of conservation. Understanding these challenges is important for both ongoing projects as well as future ones. They have impacts on the forms of care we provide and what forms of life we care for. We must work to alter the conservation narrative once more to remove 
humans from its center. Additionally, we must finally let go of the idea of pristine wilderness and recognize the world for what it is: dynamic and changing with every minute that passes. Letting go of a static nature will allow us to open our minds and envision a collective future rather than force us to linger in a anthropocentric past and present.

\section{Limitations}

Like all research, mine had its limitations. Because the 2019 summer and fall seasons were busy times in the field, some experts were unable to participate in this research. Many of these experts were identified by others as leaders in the field, therefore, their could have provided significant contributions to this research. If I were to continue on with this research, I would want to incorporate different types of local coral experts, such as an experienced citizen scientist or volunteer. I would additionally conduct a second round of interviews with experts to allow me to expand on some of these topics. Finally, I was unable to participate in coral restoration field work which I think would have given me a better understanding of the field in Florida and see coral restoration methods in actions.

\section{Future research}

Continuing social science research in this field is important and there is potential for future research to explore other factors influencing restoration goals and methodssuch as funding and politics. Further, research should look into what other groups in Florida society define as a healthy reef and how this coincides or differs from the expert 
community. While many in the expert community view the public and tourists as lacking key knowledge and understanding of reefs, this may be an over generalization. Through this research, one could assess whether this knowledge-deficit truly exists. 


\section{BIBLIOGRAPHY}

Angelini, C., Altieri, A. H., Silliman, B. R., \& Bertness, M. D. (2011). Interactions among Foundation Species and Their Consequences for Community Organization, Biodiversity, and Conservation. BioScience, 61(10), 782-789. https://doi.org/10.1525/bio.2011.61.10.8

Barbier, E.B. et al. (2011). The value of estuarine and coastal ecosystem services. Ecol. Monogr. 81,169- 183.

Bernard, H. (2011). Research Methods in Anthropology: Qualitative and Quantitative Approaches (5th ed., pp. 156-172 ). Plymouth: AltMira Press.

Bocci, P. (2017). Tangles of Care: Killing Goats to Save Tortoises on the Galapagos Islands. Cultural Anthropology, 32(3), 424-449. https://doi.org/10.14506/ca32.3.08

Boyce, H. (n.d.). Micro-Fragmenting as a Method of Reef Restoration using Montipora capricornis. Retrieved from https://www.nshss.org/media/29810/boyce.pdf

Boyer, D. (2008). Thinking through the Anthropology of Experts. Journal for Applied Anthropology in Policy and Practice, 15(2), 38-46. https://doi.org/10.3167/aia.2008.150204

Bradshaw, C., and Frederik Saltre. (2019). "Are We Really in a 6th Mass Extinction? Here's The Science." ScienceAlert. Retrieved from www.sciencealert.com/here-show-biodiversity-experts-recognise-that-we-re-midst-a-mass-extinction.

Braverman, I. (2018). Coral whisperers: Scientists on the Brink. Oakland: University of California Press.

Brumbaugh, R. Personal Communication.

Cairns, J., and J. R. Heckman. (1996). The state of emerging field. Annual Review of Energy and Environment. Restoration Ecology, 21: $167-189$.

Carrier, M. (2010). Scientific Knowledge and Scientific Expertise: Epistemic and Social Conditions of Their Trustworthiness. Analyse \& Kritik, 32(2). doi: 10.1515/auk2010-0201

Choi, Y. D. (2004). Theories for ecological restoration in changing environment: toward "futuristic" restoration. Restoration Ecology, 19:75-81. 
Choi, Y. D. (2007). Restoration Ecology to the Future : A Call for New Paradigm. Restoration Ecology, 15(2), 351-353.

Chi, M., Glaser, R., \& Farr, M. (1988). The Nature of Expertise (1st ed.). New York: Psychology Press.

Collier, C. (n.d.). "Florida Local Action Strategy." PDF file.

CRF. (2019). Retrieved from https://www.coralrestoration.org/about

Cronon, William. (1996). "The Trouble With Wilderness: Or, Getting Back To The Wrong Nature." Environmental History: n. pag. Print.

Davis, M. A., \& Slobodkin, L. B. (2004). The Science and Values of Restoration Ecology. Restoration Ecology, 12(1), 1-3.

Dayton, P. K. (1972). Toward an understanding of community resilience and the potential effects of enrichments to the benthos at McMurdo Sound, Antarctica. pp. 81-96 in Proceedings of the Colloquium on Conservation Problems Allen Press, Lawrence, Kansas.

De Groot, J., Steg, L. (2008). Value Orientations to Explain Beliefs Related to Environmental Significant BehaviorHow to Measure Egoistic, Altruistic, and Biospheric Value Orientations. Environment and Behavior, 40(May), 330-350. https://doi.org/10.1177/0013916506297831

Diersing, N. (2011). Coral Reef Evaluation and Monitoring [Ebook]. Florida Keys. Retrieved from https://nmsfloridakeys.blob.core.windows.net/floridakeysprod/media/archive/scisum maries/wqcrem.pdf

Dietz, T., Fitzgerald, A., \& Shwom, R. (2005). Environmental Values. Annual Review of Environmental Resources, 30. https://doi.org/10.1146/annurev.energy.30.050504.144444

Drake, N. (2015). "Will Humans Survive the Sixth Great Extinction?” National Geographic. Retrieved from www.nationalgeographic.com/news/2015/06/150623sixth-extinction-kolbert-animals-conservation-science-world.

Eakin, C. M. et al. (2010). Caribbean Corals in Crisis: Record Thermal Stress, Bleaching, and Mortality in 2005. PLoS ONE, 5(11). https://doi.org/10.1371/journal.pone.0013969

Enochs, I. Personal Communication. 19 October 2019. 
Ericsson, K. A. (1998). The scientific study of expert levels of performance: General implications for optimal learning and creativity. High Ability Studies, 9(1), 75-100. https://doi.org/10.1080/1359813980090106

Exec. Order No. 13089, 3 C.F.R. 115 (1998). PDF file.

"Essential Fish Habitat." (2019). NOAA. Retrieved from www.fisheries.noaa.gov/national/habitat-conservation/essential-fish-habitat.

Fagerstrom, J.A. (1987). The evolution of reef communities. United Stated: N.p.

"Florida Coral Disease." (2019). Retrieved from https://floridadep.gov/rcp/coral/content/florida-reef-tract-coral-disease-outbreak

"Florida Coral Reef Protection Act.” (2009). Florida DEP. PDF file.

Florida DEP. (2019) “Florida's Coral Reefs." Florida Department of Environmental Protection. Retrieved from floridadep.gov/rcp/rcp/content/floridas-coral-reefs.

Florida DEP. (2020). "Coral Reef Conservation Program." Florida Department of Environmental Protection. Retrieved from floridadep.gov/CoralReefs.

Florida Reef Resilience Program. (2010). "Climate Action Plan for the Florida Reef System." PDF file.

Florida Reef Resilience Program. (2013). "Florida Reef Tract Coral Bleaching Response Plan.” PDF file.

Fox, J., and Joseph Westfal. (2018) "Memorandum for the Field: Special Emphasis Given to Coral Reef Protection under the Clean Water Act, Marine Protection, Research, and Sanctuaries Act, Rivers and Harbors Act, and Federal Project Authorities." US EPA. Retrieved from www.epa.gov/cwa-404/memorandum-field-special-emphasisgiven-coral-reef-protection-under-clean-water-act-marine.

Gregg, Kurtis. Management Considerations For The Southeast Florida Coral Reef Ecosystem. NOAA CRCP And NOAA Fisheries, 2020, pp. 15-16, https://floridadep.gov/sites/default/files/FDOU_Management_Considerations_0.pd f.

Gulf of Mexico and South Atlantic Fisheries Management Councils. (1982). "Fishery Management Plan Final Environmental Impact Statement for Coral and Coral Reefs." PDF file. 
Haraway, Donna Jeanne. (2016). Staying With The Trouble. Durham: Duke University Press. Print.

Hitlin, S., \& Piliavin, J. (2004). Values: Reviving a Dormant Concept. Annual Review of Sociology, O(30), 359-393.

Hobbs, R. J. (2002). The challenge of social values and expectations. Restoration ecology, 43-48.

Hoegh-Guldberg Ove (1999) Climate change, coral bleaching and the future of the world's coral reefs. Marine and Freshwater Research 50, 839-866. Hoegh-Guldberg, O. et al. (2007). Coral Reefs Under Rapid Climate Change and Ocean Acidification. American Association for the Advancement of Science, 318(5857), 1737-1742.

Hoegh-guldberg, O. (2011). Coral reef ecosystems and anthropogenic climate change. Regional Environmental Change, 11, 215-227. https://doi.org/10.1007/s10113-0100189-2

Hughes, T. P. et al. (2017). Global warming transforms coral reef assemblages. Nature, 556(7702), 492-496. https://doi.org/10.1038/s41586-018-0041-2

IUCN. (2019). "There Is Hope For The Ocean." IUCN. N.p., Web.

Jackson, J., M. Donovan, K. Cramer, and V. Lam. 2014. Status and trends of Caribbean coral reefs: 1970-2012. Report, Washington, D.C.

Johnson, L. (2019). "A Scientific Breakthrough at the Florida Aquarium Could Save 'America's Great Barrier Reef." CNN. Retrieved from edition.cnn.com/2019/08/21/us/historic-coral-discovery-scn-trnd/index.html.

Kleypas, J. A. et al. (2020). Geochemical Consequences of Increased Atmospheric Carbon Dioxide on Coral Reefs. American Association for the Advancement of Science, 284(5411), 118-120.

Knowlton, N., R. E. Brainard, R. Fisher, M. Moews, L. Plaisance, and M. J. Caley. 2010. Coral reef biodiversity. Pages 65-74 in A. Macintyre, editor. Life in the world's oceans: diversity distribution and abundance. Wiley-Blackwell, Oxford, UK.

Latour, Bruno. (1987). Science In Action. Cambridge: Harvard University Press. Print.

Levy, J., Ripple, K., and R. S. Winters (2018). "Lessons learned for increased scalability for in situ coral restoration efforts [White paper].” Accessed 4 Mar. 2019. PDF file from Coral Restoration Foundation. 
Lessios, H. A. (2016). The great Diadema antillarum die-off: 30 years later. Annual review of marine science, 8, 267-283.

Listing of Elkhorn. (2018). Retrieved from https://www.fisheries.noaa.gov/action/listingelkhorn-and-staghorn-corals-under-esa

Lorimer, Jamie. (2015). Wildlife In The Anthropocene. Minneapolis: University of Minnesota Press. Print.

Loya, Y., et al., 2001. Coral bleaching: the winners and the losers. Ecol. Lett. 4, 122-131.

Moberg, Fredrik, and Carl Folke. (1999). Ecological Goods And Services Of Coral Reef Ecosystems. Ecological Economics 29.2: 215-233. Print.

Moore, T. Personal Communication. 12 July 2019.

Muir, John. (1894). The Mountains Of California. Web.

NOAA. (2011). “How Do Corals Reproduce?” Florida Keys National Marine Sanctuary. Retrieved from floridakeys.noaa.gov/corals/reproduce.html.

NOAA. (2019). Florida Keys National Marine Sanctuary. Retrieved from https://floridakeys.noaa.gov/regs/

NOAA CRCP. (n.d.) "NOAA's Coral Reef Conservation Program (CRCP).” US NOAA. Retrieved from coralreef.noaa.gov/about/welcome.html. Accessed 30 Jan. 2020.

Page, C. A., Muller, E. M., \& Vaughan, D. E. (2018). Microfragmenting for the successful restoration of slow growing massive corals. Ecological Engineering, 123(January), 86-94. https://doi.org/10.1016/j.ecoleng.2018.08.017

Patterson, J. Personal Communication.

Parreñas, Juno Salazar. (2018). Decolonizing Extinction. 1st ed. Durham and London: Duke University Press. Print.

Pauly, D. (1995). Anecdotes and the shifting baseline syndrome of fisheries. Trends in ecology \& evolution, 10(10), 430.

Personal Communication. 2019. 
Reef Renewal. (2019). Retrieved from https://reefrenewalbonaire.org/about/mission-andhistory/.

Robson, C., \& McCartan, K. (2016). Real world research (4th ed., pp. 24, 284-292). Chichester: John Wiley \& Sons Ltd.

Ross, W. et al. (2019). "Draft Environmental Statement for Florida Keys National Marine Sanctuary: A Restoration Blueprint.” PDF file.

Selkoe, K. et al. (2011). A map of human impacts to a 'pristine' coral reef ecosystem, the Papahanaumokuakea Marine National Monument. Coral Reefs, 28(2009), 635-650. https://doi.org/10.1007/s00338-009-0490-z

Stern, P. C. (2000). Toward a Coherent Theory of Environmentally Significant Behavior. Journal of Social Issues, 56(3), 407-424.

Subramaniam, Banu. (2014). Ghost Stories For Darwin. Urbana, Chicago, and Springfield: University of Illinois Press. Print.

The Nature Conservancy. (2020). "Field-Based Nurseries." Reef Resilience Network.

Retrieved from reefresilience.org/restoration/coral-populations/coralgardening/field-based-nurseries.

"Threats to Coral Reefs." (2018). Retrieved from https://www.epa.gov/coralreefs/threats-coral-reefs.

Toths, Lauren. (2018). "The Development And Demise Of Florida'S Coral Reefs". Retrieved from https://www.usgs.gov/center-news/development-anddemise-florida-s-coral-reefs?qt-news_science_products $=3 \# q t-$ news_science_products.

USCRTF. (2000). "The National Action Plan to Conserve Coral Reefs." PDF file.

USCRTF. (2017). “About the U.S. Coral Reef Task Force.” Retrieved from www.coralreef.gov/about.

USFMC. (2020). "Home". U.S. Regional Fishery Management Councils, Retrieved from http://www.fisherycouncils.org/.

USGS. (n.d.) "Black-Band Disease in the Florida Keys." United Stated Geological Survey. Retrieved from www.usgs.gov/centers/spcmsc/science/black-band-disease- 
florida-keys?qt-science_center_objects=0\#qt-science_center_objects. Accessed 4 Mar. 2020.

Vaughan, T. (1914). Sketch of the geologic history of the Florida coral reef tract and comparisons with other coral reef areas. Journal of the Washington Academy of Sciences, 4(2), 26-34.

Vevers, R. Personal Communication.

Western, D. (2001). Human-modified ecosystems and future evolution. Wildlife Conservation Society 98(10).

Wilkinson, C., Souter, D. (2008). Status of Caribbean coral reefs after bleaching and hurricanes in 2005. Global Coral Reef Monitoring Network, and Reef and Rainforest Research Centre, Townsville, 152

Woodward, A. (2019). "18 Signs We're in the Middle of the 6th Mass Extinction." Business Insider. Retrieved from https://www.businessinsider.com/signs-of-6thmass-extinction-2019-3.

Zaneveld, J. R. et al. (2016). Overfishing and nutrient pollution interact with temperature to disrupt coral reefs down to microbial scales. Nature Communications, (May), 112. https://doi.org/10.1038/ncomms 11833 